\title{
Are adaptations self-organized, autonomous, and harmonious? Assessing the social-ecological resilience literature
}

\author{
Thomas Hahn ${ }^{1}$ and Björn Nykvist ${ }^{1,2}$
}

\begin{abstract}
The paper analyzes how adaptability (adaptive capacity and adaptations) is constructed in the literature on resilience of social-ecological systems (SES). According to some critics, this literature views adaptability as the capacity of SES to self-organize in an autonomous harmonious consensus-building process, ignoring strategies, conflicting goals, and power issues. We assessed 183 papers, coding two dimensions of adaptability: autonomous vs. intentional and descriptive vs. normative. We found a plurality of framings, where $51 \%$ of the papers perceived adaptability as autonomous, but one-third constructed adaptability as intentional processes driven by stakeholders; where social learning and networking are often used as strategies for changing power structures and achieving sustainability transformations. For the other dimension, adaptability was used normatively in $59 \%$ of the assessed papers, but onethird used descriptive framings. We found no evidence that the SES literature in general assumes a priori that adaptations are harmonious consensus-building processes. It is, rather, conflicts that are assumed, not spelled out, and assertions of "desirable" that are often not clarified by reference to policy documents or explicit normative frameworks. We discuss alternative definitions of adaptability and transformability to clarify or avoid the notion of desirability. Complex adaptive systems framing often precludes analysis of agency, but lately self-organization and emergence have been used to study actors with intentions, strategies, and conflicting interests. Transformations and power structures are increasingly being addressed in the SES literature. We conclude that ontological clashes between social science and SES research have resulted in multiple constructive pathways.
\end{abstract}

Key Words: adaptive comanagement; adaptive governance; ecosystems; neoliberalism; structured literature review; sustainable development goals; transformability

\section{INTRODUCTION}

Research on resilience of social-ecological systems (SES) originates from ecology and complex adaptive systems (CAS), focusing on ecological resilience, tipping points, feedbacks, selforganization, and other system properties (Berkes and Folke 1998). The recent shift in focus from resilience of ecosystems to resilience of SES has attracted - and has partly been driven bysocial scientists, especially on adaptation and transformation issues. In social science, both adaptation (as action) and adaptability (adaptive capacity) concern agency, i.e., real actors with intentions and conflicting strategies in specific contexts (Nelson et al. 2007). Social science frameworks, therefore, often clash with CAS frameworks, where adaptations in ecosystems are seen as emergent properties of local interacting but autonomous parts (Levin 1998).

There has been a heated debate on whether the research field of SES resilience is still based on ecological ontologies or whether it has changed into a truly interdisciplinary research field that enhances understanding of the coevolution of intertwined social and ecological systems (Folke et al. 2010). According to some authors, this change has already occurred through significant advances in analyzing agency, especially in relation to transformations, focusing on learning, innovation, leadership, and "changes to practices, lifestyles, power relations, norms and values" (Brown 2014:113). Power, agency, and justice issues belong to the priorities for future SES research (Olsson et al. 2014, Fischer et al. 2015). Other authors emphasize the lack of change (Leach 2008, Hornborg 2009, Hatt 2012), claiming that the SES literature views resilience and the necessary adaptations and adaptability as autonomous (spontaneous) and harmonious, assuming consensus building. Nelson et al. (2007:409) argue that the idealized situation - of testing and revising management and institutions based on ecological knowledge in a self-organized process - is rare, and that this approach may reinforce existing inequalities if power relationships are ignored. Cote and Nightingale (2012) suggest that the shortcomings in addressing power relationships and conflicting interests in SES research is due to an assumption that social and ecological systems are essentially similar.

Much of the critique of the SES literature can be codified into two propositions: (i) it uses a framing of autonomous selforganization, which precludes analysis of intentional agents, conflicts, and power; and (ii) it uses a normative framing. By "normative," we mean statements that assume an underling norm of what is desirable. Facts become normative when they "are interpreted through the filter of an assumption that implies an inherent policy preference" (Lackey 2001:439).

In the context of sustainable adaptations, Brown (2011:29) uses resilience as a normative concept, the opposite of vulnerability, and points to "the need for fundamental institutional reconfiguration in support of long-term equity and resilience." Hence, social change is necessary for resilience. Other authors make the opposite normative association, equating resilience with social stability (MacKinnon and Derickson 2013), and by associating it to functionalism, arguing "that resilience appears conservative when extended to social change and social relations" (Olsson et al. 2015:6). Assumptions of desirability in the very definitions of adaptability and transformability have also been criticized (Leach 2008). 
Normative issues have been clearly recognized within vulnerability research (Adger 2006, Smit and Wandel 2006), but resilience research has been criticized for often leaving agency and normative statements unclear (Duit et al. 2010, Robards et al. 2011). Brown (2014) shares this critique but argues that the resilience literature contains multiple framings, resulting in rich scholarship. However, a quantitative analysis of agency and normativity has not yet been conducted, and we believe that would enrich this important critical discussion. Therefore, we conduct a quantitative structured literature review to test three hypotheses:

1. The literature on resilience of SES treats adaptability as a capacity of a system to self-organize in an autonomous way, i.e., with no description of actors with intentions and strategies;

2. The literature on resilience of SES makes normative judgements concerning what are "desirable" adaptations; and

3. Power issues and transformations are increasingly being addressed in the SES literature.

This paper is organized in the following way. In the theory section, we analyze contested theoretical and conceptual issues. This is followed by a description of the methods for the structured literature review. We discuss the quantitative results together with the theoretical findings and close by drawing conclusions that inform future research and application of SES resilience concepts.

\section{THEORY}

In this section, we analyze different conceptualizations of CAS behavior and discuss definitions of core SES resilience concepts.

\section{Contested definitions}

Some critique of the literature on SES resilience (henceforth called SES literature) relates to the very definitions of resilience, adaptability, and transformability, so let us first reflect on this. Resilience is primarily defined analytically/descriptively in a set of well-cited seminal conceptual papers (e.g., Walker et al. 2004, Folke 2006, Folke et al. 2010). In Walker et al. (2004), resilience (of SES) was defined as "the capacity of a system to absorb disturbance and reorganize while undergoing change so as to still retain essentially the same function, structure, identity, and feedbacks," and adaptability was defined as "the capacity of actors in a system to influence resilience." This separation between resilience and adaptability caused some confusion (see also Gallopin 2006, Folke et al. 2010:2). Folke (2006) instead argued that resilience of SES "incorporates the idea of adaptation, learning and self-organization in addition to the general ability to persist disturbance," making adaptability a part of resilience.

Resilience is used normatively primarily in relation to explicit goals or normative frameworks on natural resource management, like the Millennium Ecosystem Assessment (MA 2005b). Adaptability, on the other hand, is often referred to as explicitly normative, determining whether the actors "can successfully avoid crossing into an undesirable system regime" (Walker et al. 2004:3) or "to respond to and shape ecosystem dynamics and change in an informed manner" (Folke 2006:262).

Related to adaptability, but somehow opposite, is transformability, which in the SES literature is about (often deliberatively) eroding resilience of the present state or development path. It is "the capacity to create a fundamentally new system when ecological, economic, or social structures make the existing system untenable" (Walker et al. 2004). Hence, assumptions on what is undesirable or untenable are often made in the conceptualization of adaptability and transformability. We will return to this issue in the next section.

In a multiscale framework, transformability may be viewed as part of resilience in the sense that transformational change at smaller scales (e.g., sectors such as energy or farming systems) may be required for adaptations and hence resilience at larger scales, ultimately the planetary scale (Folke et al. 2010). Therefore, staying within the "planetary boundaries" (Steffen et al. 2015) is about resilience - and it is also a call for major transformations. This is noted by Brown (2014:112) in her critical discussion of the SES literature, but other critics do not appreciate that transformation can be part of the same systems analysis as resilience and still "be in contrast to resilience" (Olsson et al. 2015:2). They seem to interpret the resilience literature as a norm that SES (of whatever state and scale) should be resilient, and that resilient means robust and stable. We call this the "stability fallacy," and note that sustainable development also can be misrepresented as a norm to sustain the present development and social order and hence promote status quo.

\section{Self-organization and desirable states}

Already in 1973, Hayek (2012) referred to the market economy as a self-organized "spontaneous order" with market prices being the emergent properties. This framing has served to depoliticize market prices in neoclassical economics, and Bromley (1990, 1998) has criticized the belief that the "spontaneous order" of the free market results in objective prices and promotes efficiency. Hatt (2012:5) has argued that there is "a close affinity between Holling's approach to resilience and Friedrich Hayek's neoliberal economics and their reliance on complex systems theory."

However, the self-organization of CAS may not necessarily be employed to legitimize the present or any other desired social order; it seems rather strange to associate a scientific approach (resilience or CAS) to a political ideology. In a contrasting example, Brown (2014:113) discusses transition towns and argues that "[c]ounter to the argument about resilience as supporting regressive and neoliberal agendas, resilience is being used as an organizing principle by communities to challenge the status quo and to design and shape alternative futures."

Central to this debate on self-organization are the concepts of scale and emergence. In CAS frameworks, actors are often observed from the outside, e.g., from a higher level of a spatial or institutional panarchy (Holling 2001). Such analytical frameworks tend to view the unfolding of events and adaptations made in the system as autonomous and emergent, with adaptation being an inherent self-organized property of CAS (Levin 1999). However, the interaction between agents that results in emerging properties need not be autonomous but may include "players and strategies" (Lansing 2003:196). In SES, self-organization is often used for processes occurring at lower organizational levels, for example, when Ostrom et al. (1999:281) observe that "[n]ational governments can help or hinder local self-organization" or when Folke (2006:260) suggests that self-organization is the opposite of either "lack of organization, or organization forced by external factors." If an ideological interpretation must be made, the two 
citations above may reflect a preference for decentralization and voluntary action rather than a preference for Hayek's spontaneous order. Indeed, self-organization in the field of SES research often refers to voluntary organization without assuming harmonious or autonomous processes. For example, Österblom and Folke (2013:2) employ a CAS perspective to study how global governance to combat illegal fishing emerged from interaction among key persons who managed to mobilize networks and formalize cooperation.

Holling's (2001:403) argument that "Self-organization of human institutional patterns establishes the arena for future sustainable opportunity" makes sense from a larger-scale systems perspective, but clearly abstracts from the strategies, leadership, conflicts, alliances, and power imbalances of human actors. However, abstracting from these issues is not the same thing as assuming that adaptations occur harmoniously through consensus; indeed, it says nothing about how adaptations actually occur and gives no information on the strategies, power structures, conflicts, and leadership underlying adaptability.

If we want to understand "the art" of adaptations and transformations, i.e., the personal skills and networks of key change agents navigating the unexpected (Westley 2002, Westley et al. 2013), and not just the need for it, we need to analyze agency in specific contexts. As long as there are plural opinions of what ends society should promote, what means should be employed, and how trade-offs should be dealt with, there will be conflicting interests. This applies even in the case of global consensus on the ends, which the United Nations (2015) suggests exists for the new Sustainable Development Goals. There are often strong economic incentives for actors in SES to strategically plan, advocate, or simply coerce a different state or development trajectory than the one envisioned by the norm of success applied or assumed in the scientific analysis. For example, in a study of water governance in Sweden, Galaz (2005) showed that some actors blocked attempts for social learning and adaptations desired by other stakeholders, an act of obstruction of change linked to the institutional setup where hydropower concessions have been unlimited in time in Sweden (Rudberg et al. 2015).

Ideally, normative statements in science, e.g., assertions of what is desirable, should be evidenced by an explicit reference to a policy document or scientific-political framework with clearly expressed norms like the MA (2005b) or the new Sustainable Development Goals. For instance, claims that a clear lake is more "desirable" than a turbid lake are typically normative statements, but beg the question "for whom" or according to what policy framework? If clear lakes are desirable by all or most people in a society and lakes still become turbid, is it due to lack of knowledge or some actors driven by strong monetary incentives or something else?

In the context of natural resource management, an ecosystem that is approaching an "undesirable" threshold according to some actors and that is therefore not assessed as resilient in an ecological sense, may nevertheless be resilient in a social-ecological sense. This is the case if these actors show high adaptability and are able "to respond to change and restore the lake" (Folke et al. 2005:444). Hence, when shifting the perspective from ecosystems to SES, a more explicit reference to agency and normative issues concerning adaptability can be expected.

\section{The harmonious consensus critique}

Fuzzy notions of desirability and agency are targeted in the critique that the SES literature portrays adaptations as harmonious consensus building (e.g., Nelson et al. 2007:409, Leach 2008:1791, Hornborg 2009:252, Hatt 2012:3-5, Olsson et al. 2015:4-5). These critics have explicitly referred to seven articles or books together: Berkes and Folke (1998), Berkes et al. (2003), Folke et al. (2005), Olsson et al. (2004a, 2006), Walker et al. (2006a), and Westley et al. (2002). We have analyzed these seven texts with special emphasis on how they treat the concepts of functionalism, consensus, collaboration, conflict, and shared vision in adaptability.

Functionalism was explicitly referred to only once (in Westley et al. (2002)) but not in the way the critics suggest; there is no preference expressed for maintaining or justifying the existing social order. Other texts (e.g., Berkes et al. 2003:364) discuss different "functions" or roles by key persons to accomplish a transformation: some act as visionaries, others as knowledge carriers, networkers, facilitators, entrepreneurs , and implementers; again, not to maintain the existing social order, but rather the opposite.

We found no assumptions on consensus, but some texts described shared visions: "Trust-building dialogues [...] collaborative learning, and creating public awareness were part of the process. A comprehensive framework with a shared vision and goals that presented conservation as development and turned problems into opportunities was developed and contributed to a shift in values and meaning of the wetland landscape among key actors" (Folke et al. 2005:457).

The citation above by Folke et al. (2005) and the empirical papers it referred to suggest that consensus or harmonious processes are not assumed a priori. The processes for building trust, solving conflicts, and identifying common interests are studied empirically in the case studies described and involve key persons building alliances (networks) among diverse stakeholder groups. Although rarely made explicit, such networking is generally a strategy for changing power structures, and these are not smooth, harmonious processes (Hahn 2011, Crona and Parker 2012). Olsson et al. (2014:4) admit that power is understudied in the SES literature but note that this is changing and that "the redistribution and sharing of power is one of the key conditions for more flexible, collaborative forms of management and governance that contribute to long-term resilience of socialecological systems." Thus, the SES literature cannot be said to assume harmonious consensus building. Conflicting interests are often implicitly acknowledged (networks are developed to change business-as-usual management and achieve a transformation), so it is rather the "conflicts" that are often assumed, not spelled out.

A high degree of consensus may be achieved in situations of "low politics" (Klijn and Skelcher 2007:596), i.e., when stakes are not high. However, voluntary collaboration is not a panacea, and the SES literature does not generally assume that a voluntary approach to collaborative adaptive governance is sufficient to achieve adaptations or transformation when stakes are high. As discussed before, the SES literature often acknowledges that major actors may obstruct any such process unless they are coerced or otherwise maneuvered to change. For example, turning one-third of the Great Barrier Reef into a marine protected area 
started as a collaborative learning process but eventually required political coercion to handle the opposition from fishermen (Olsson et al. 2008). Political coercion was also decisive for curbing illegal and unreported overfishing in the Southern Ocean but, interestingly, the coercion was enabled by a long process of trust building and collaboration between NGOs and civil servants in international networks (Österblom and Sumaila 2011). Thus, trust building, knowledge generation, and collaboration in networks can be an effective strategy for catalyzing government coercion and changing power structures.

\section{METHODS}

For the first two research questions, we used a structured literature review, an approach common to both social science (Petticrew and Roberts 2006) and natural science (Fink 2005). This part of the analysis was conducted in 2011-2012 (Nykvist 2012), a time when the strongest critiques of SES resilience were being published. We started by developing coding criteria for different conceptualizations of adaptability (Tables 1 and 2). We used the ISI Web of Science database and searched for articles published before 1 January 2011, matching ("social-ecological system*" OR "socio-ecological system*" AND resilience AND adapt*) in title, abstract, and keywords. We used the truncated expression of "adapt*" because we view adaptability as an inclusive concept including adaptive capacity, adaptiveness, and adaptations. The search yielded 193 papers, dating back to 2001. For the third research question, we made a simple quantitative assessment of all 798 papers on resilience, adaptability, and SES published 20012015, adding either the words "power" and "transform*" to the search. For each of these two added concepts, we did one analysis for every year to assess possible trends.

Table 1. Coding of research question 1, autonomous vs. intentional. Each row represents sufficient but not necessary conditions

\begin{tabular}{|c|c|}
\hline Autonomous & Intentional \\
\hline $\begin{array}{l}\text { Adaptations are characterized as } \\
\text { autonomous, that is } \\
\text { spontaneously self-organized. }\end{array}$ & $\begin{array}{l}\text { Adaptations are characterized as } \\
\text { intentional and strategically } \\
\text { planned. }\end{array}$ \\
\hline $\begin{array}{l}\text { No discussion of actors' } \\
\text { strategies, agendas, or leadership } \\
\text { occur. }\end{array}$ & $\begin{array}{l}\text { The ways actors organize in order } \\
\text { to adapt a SES toward a certain } \\
\text { goal are described or analyzed. }\end{array}$ \\
\hline $\begin{array}{l}\text { Actors can be assumed to have } \\
\text { intentions or preferences in } \\
\text { modeling. }\end{array}$ & $\begin{array}{l}\text { The strategies or agendas of real } \\
\text { actors are analyzed. }\end{array}$ \\
\hline
\end{tabular}

For research questions 1 and 2, each paper was searched for each occurrence of paragraphs containing "adapt*." These paragraphs were read, and key statements including definitions, descriptions, or discussions of adaptability were marked. Ten papers were excluded from the study because they actually had no discussions of adaptability in the text, despite passing the search criteria. We critically appraised the remaining 183 papers, analyzing the paragraphs including the word "adapt*" using our coding scheme (Tables 1 and 2) and we categorized the papers according to the two coding dimensions (Table 3 ). For research question 1 , we were not able to code four further papers due to lack of definitions or descriptions. These papers are also excluded in our quantitative results. By having clear predefined categories and by discussing uncertain papers, we tried to minimize the inevitable subjective element of interpretation. Examples of our interpretations are provided in the results section. For more examples of coding and categorization of the 183 papers, see the Appendix (Tables A1A3). It is important to understand that this method allowed no evaluation of the papers as a whole, only how adaptability was conceptualized and used.

Table 2. Coding of research question 2, descriptive vs. normative. Each row represents sufficient but not necessary conditions.

\begin{tabular}{|c|c|c|}
\hline Descriptive & Normative & Vaguely normative \\
\hline $\begin{array}{l}\text { Adaptability related to } \\
\text { how actors in the SES } \\
\text { react to change, how } \\
\text { they adapt no matter } \\
\text { the outcome; no room } \\
\text { for "maladaptations" } \\
\text { and no normative } \\
\text { connotations. }\end{array}$ & $\begin{array}{l}\text { There is a clearly stated } \\
\text { norm or goal, e.g., } \\
\text { criteria for a well- } \\
\text { functioning ecosystem, } \\
\text { or a particular } \\
\text { ecosystem state (such } \\
\text { as clear water) or } \\
\text { avoiding crossing a } \\
\text { threshold to an } \\
\text { undesirable state. }\end{array}$ & $\begin{array}{l}\text { No specific norm is } \\
\text { applied, there is only a } \\
\text { "need for adaptation" } \\
\text { or adaptability is used } \\
\text { as an antonym to } \\
\text { vulnerability or } \\
\text { maladaptation. }\end{array}$ \\
\hline $\begin{array}{l}\text { Actors' strategies or } \\
\text { leadership are } \\
\text { described, but no } \\
\text { norm or direction of } \\
\text { what is a desirable } \\
\text { adaptability is offered. }\end{array}$ & $\begin{array}{l}\text { Adaptability is } \\
\text { assumed to facilitate or } \\
\text { enhance something } \\
\text { clearly normative, e.g., } \\
\text { sustainable } \\
\text { development or a } \\
\text { desired SES. }\end{array}$ & $\begin{array}{l}\text { Adaptability is } \\
\text { important for } \\
\text { enhancing resilience or } \\
\text { learning, without giving } \\
\text { resilience or learning an } \\
\text { explicit normative } \\
\text { meaning. }\end{array}$ \\
\hline
\end{tabular}

Drawing on Smit and Wandel (2006:288), we operationalized research question 1 by identifying the difference between viewing adaptations as either autonomous or intentional/planned. Adaptations were considered autonomous if they are framed only as self-organized or react according to modeled preferences, e.g., in agent-based models. Agent-based modeling (ABM) can, of course, model strategies, conflicting interests, collaborations, and hence power issues, but we decided to interpret such frameworks as autonomous as the self-organization is autonomous and deterministic. Adaptations were considered intentional if they are described as strategically planned or organized by "real" actors. Intentional framings may or may not include analysis of leadership, conflicting interests, and/or power. General statements that strategies or leadership are important, or that stakeholders need to be considered, do not qualify for a categorization as intentional (see Table 1). Some papers used both intentional and autonomous framings, and we coded these as "Both perspectives."

Research question 2 concerns normative vs. descriptive framings. In a descriptive/analytical framing, adaptability refers to the capacity to adapt, whatever end or outcome. In explicit normative contexts, adaptability is the capacity to enhance the resilience of what is seen as a desirable ecosystem state or trajectory. However, sometimes there is no explicit reference to what is desirable, e.g., when adaptability is just assumed to be good or when adaptability is used in an instrumental way, expected to enhance resilience or learning without giving resilience or learning an explicit normative meaning. We refer to such statements as "vaguely normative" (see Table 2). Some papers used both normative (or vaguely normative) and descriptive framings. We coded these as "Several perspectives." 
Table 3. The six possible combinations of framings. For exact coding of each framing, see Methods.

\begin{tabular}{|c|c|c|c|}
\hline & Descriptive & Normative & Vaguely normative \\
\hline Autonomous & $\begin{array}{l}\text { Descriptive analysis of how the SES } \\
\text { adapts to change, no evaluation of } \\
\text { outcomes toward a particular norm. } \\
\text { No room for maladaptations and no } \\
\text { discussion of actors' strategies or } \\
\text { agendas, actors are reactive or } \\
\text { autonomous. }\end{array}$ & $\begin{array}{l}\text { The SES has a clearly defined desirable state } \\
\text { (e.g., coral reef or grassland), or adaptability } \\
\text { is clearly linked to sustainability, or resilience, } \\
\text { which in turn is normatively discussed. } \\
\text { The actors' strategies or agendas are not } \\
\text { described, actors are reactive or autonomous. }\end{array}$ & $\begin{array}{l}\text { There is a "need for adaptations," but the } \\
\text { reasons for this are not discussed: } \\
\text { resilience of what and for whom is } \\
\text { unclear. No discussion of actors' } \\
\text { strategies or agendas, actors are reactive } \\
\text { or autonomous. }\end{array}$ \\
\hline Intentional & $\begin{array}{l}\text { Descriptive analysis of how the SES } \\
\text { adapts to external drivers, no } \\
\text { evaluation of outcomes toward a } \\
\text { particular norm. } \\
\text { Actors and their intentions or } \\
\text { strategies for adaptation are discussed. }\end{array}$ & $\begin{array}{l}\text { Analysis of how actors organize and adapt } \\
\text { with the aim to enhance resilience of a clearly } \\
\text { defined desirable SES, or adapt and change } \\
\text { the SES along a more desirable trajectory. }\end{array}$ & $\begin{array}{l}\text { Adaptation is described as something } \\
\text { positive, but reasons for this are not } \\
\text { discussed. Actors and their intentions } \\
\text { and strategies for adaptation are } \\
\text { discussed. }\end{array}$ \\
\hline
\end{tabular}

\section{RESULTS}

Coding for the structured literature review

The 183 papers matching our search criteria were published in 62 journals (Fig. 1), of which Ecology and Society accounted for onethird of the papers $(56 / 183)$.

\section{Autonomous vs. intentional}

More than half of the papers (51\%) explicitly or implicitly refer to adaptations as autonomous only (Fig. 2A), often in the context of a complex adaptive system (CAS), or explained through the four phases of the adaptive cycle (Holling 2001). This set of papers thus provides no information on intentions, strategic planning, leadership, or power in relation to adaptability. For $31 \%$ of the papers, intentions and strategies are discussed in relation to adaptability. Finally, $17 \%$ of the reviewed papers include definitions and discussions of adaptability as both intentional and autonomous. This is often the case for review papers or theoretical papers that discuss several uses and references of adaptability.

\section{Descriptive vs. normative}

Taken together, explicitly and vaguely normative references and discussions of adaptability were almost twice as common as a descriptive framing (59\% compared with 33\% in Fig. 2B). Only $8 \%$ of the papers used descriptive as well as (vaguely) normative framings. The combination of framings is illustrated in Fig. 2C.

\section{Categories of adaptability}

When combining the two analytical dimensions, six types of references to adaptability emerge (see Table 3). A categorization of each individual paper is found in the Appendix (Tables A2 and A3). In the following presentation of results, we merge the categories of normative and vaguely normative and provide illustrations and discussion of the four major categories: Autonomous-Descriptive, Autonomous-Normative, IntentionalDescriptive, and Intentional-Normative. Each category is illustrated by a few citations. Fig. 3 shows the number of papers per year and the proportions of the four categories.

\section{Autonomous and descriptive}

A combination of descriptive and autonomous framings were found in $17 \%$ of the papers (Fig. 2C). This is a classical natural science analysis of SES as CAS, without discussions of adaptability in relation to intentions and strategies, and without making explicit any system state as more or less desirable. Two citations demonstrate typical contexts. The first involves decisions based on modeling, not real actors, and we refer to this as autonomous (see Methods above). The second citation describes income as a factor determining adaptability without any desired norm.

In adaptive management, chosen strategies are seen as experiments that provide information about the system that is being managed, which can be used to refine future strategies [...] Every time an agent makes a decision, it is based on past and learned experiences and is, therefore, adaptive. (Bodin and Norberg 2005:175-177).

Households with a higher and more diverse endowment of these different forms of capital are more capable of coping with perturbations and adapting to change. [...] This diversity of income sources is an adaptive response to variable and unpredictable biophysical and socioeconomic environments, but despite this many households in rural areas are chronically poor. (Vetter 2009:32)

\section{Autonomous and normative}

This combination is indeed the most common, appearing in 33\% of reviewed material (Fig. 2C). As mentioned before, actors and their intentions or strategies may be discussed in these papers, but if so, such discussions are not related to the adaptability concept. The first citation below combines CAS with a vaguely normative (best fit) outcome. The second uses adaptive capacity vaguely normatively yet includes no reference to intentions or strategies. The third adopts an explicitly normative view but offers no information on how adaptability is self-organized.

These [community-based conservation] institutions can be conceptualized as complex adaptive systems because they are composed of interacting agents, have emergent properties resulting from agent interactions, can selforganize to find the best fit with the environment [...] adapt and reorganize during and following the decadelong Maoist insurgency in Nepal. (Baral et al. 2010:1-3) 
Fig. 1. The 62 journals of the 183 papers for the years 2001-2010.

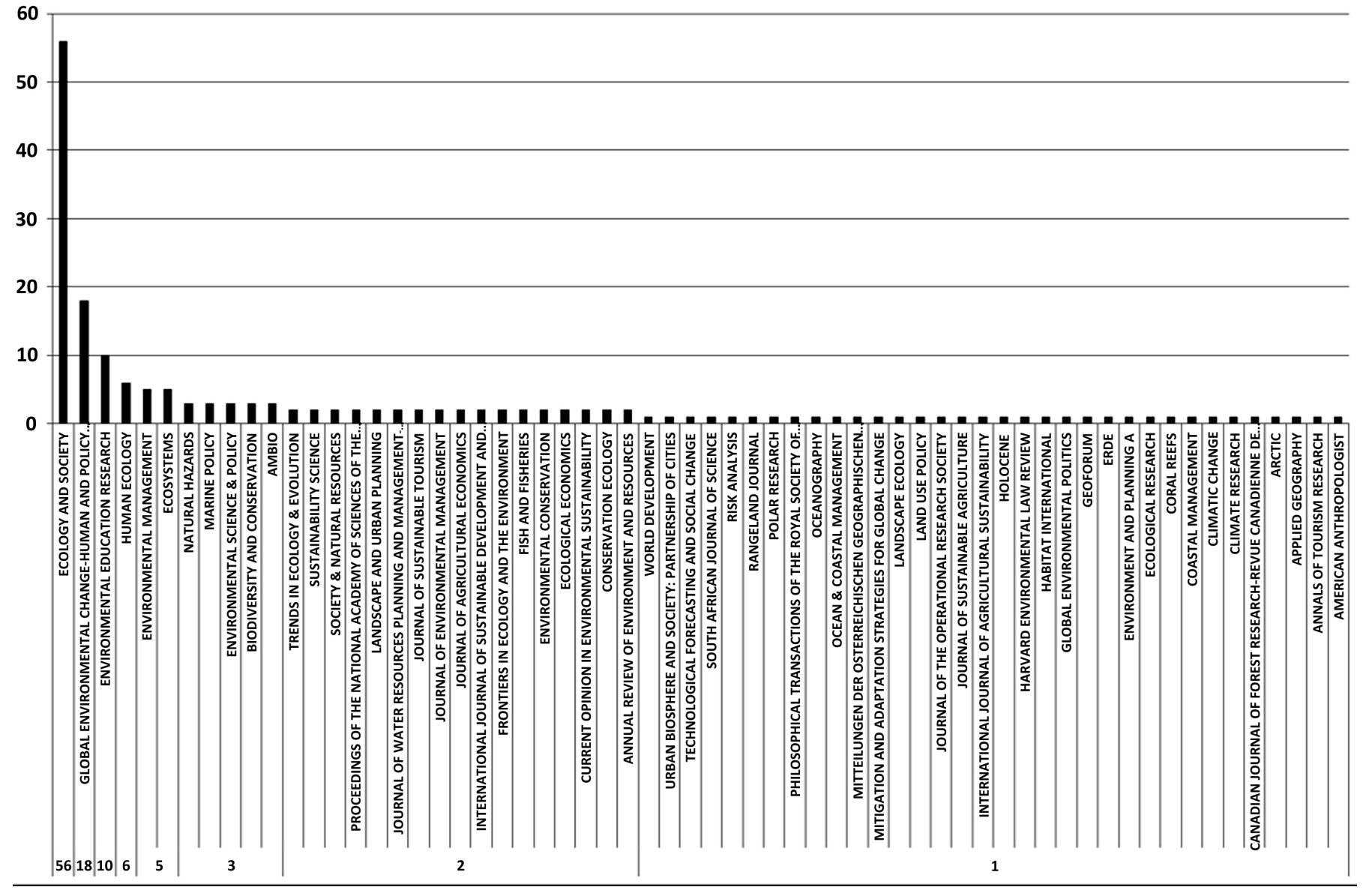

Evaluation of parameters that indicate the system's adaptive capacity could, at least, be employed to check that proposed risk treatments are unlikely to reduce system resilience. The adaptive capacity of the system could also be used to provide an indication of its ability to respond to unforeseen impacts and disturbances. Adaptive capacity, therefore, becomes a measure of system performance that improves risk management and that could be included in the suite of performance measures used to evaluate sustainability.(Blackmore and Plant 2008:231)

Interstate and national initiatives have established a watertrading system coupled with a system of catchment-scale regulatory water plans. If this system proves to be moreor-less self-organizing, encourages innovation and adaptation, and reduces salinity and water-table rise, it should enhance resilience. (Walker et al. 2009:20)

\section{Intentional and descriptive}

Some papers discuss adaptability in relation to actors' intentions and/or strategies but do not connect this to normative or prescriptive statements. This combination accounts for only $12 \%$ of the papers. It is common for descriptions of adaptive comanagement processes. Below, we cite two rather conceptual papers. The first citation describes a clash of framing and finds the normative definitions within adaptive governance inadequate. The second emphasizes intentions and politics and provides no normative meaning of adaptability.

Rather than the implementation of singular plans, adaptive governance emphasises the interaction of multiple institutions in guiding a complex system towards some more favourable state or trajectory (transformability) or maintaining it in a desired state or trajectory (resilience) (Walker et al. 2006a). Accepting that the outcomes of intervention will remain uncertain, adaptive governance emphasises flexibility, experimentation, and learning as strategies for anticipating and dealing with unintended consequences. Such governance approaches are thus deemed appropriate to situations of rapid change and high uncertainty. Nevertheless, they tend to assume that there are shared goals around what system properties should remain resilient, or that consensus can be built through the governance process. In this respect, adaptive governance is inadequate to deal with the kinds of clash of framing and value that emerge in the case studies I have described. (Leach 2008:1791)

... adaptation is not a predetermined outcome that arises deterministically from biophysical considerations. It 
depends on human agency, including the role of individuals, collective movements, leaders, and institutions, and it often involves political struggle. (O’Brien et al. 2009:11)

Fig. 2. (a) Autonomous vs. intentional. "Both" refers to discussions of adaptability where reference is made to both perspectives. (b) Descriptive vs. normative and vaguely normative. "Several perspectives" means using descriptive as well as (vaguely) normative framings of adaptability. (c) Categories of adaptability. The combination autonomous and normative is most common framing, appearing in $33 \%$ of the categorized papers.

a)

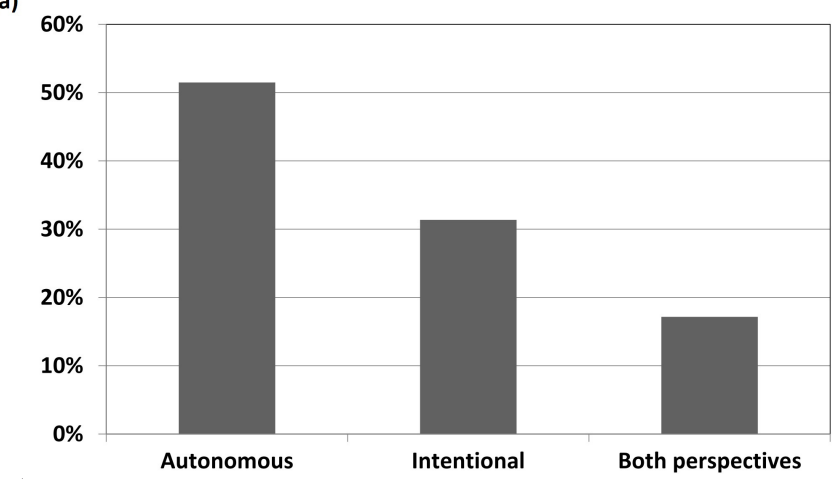

b)

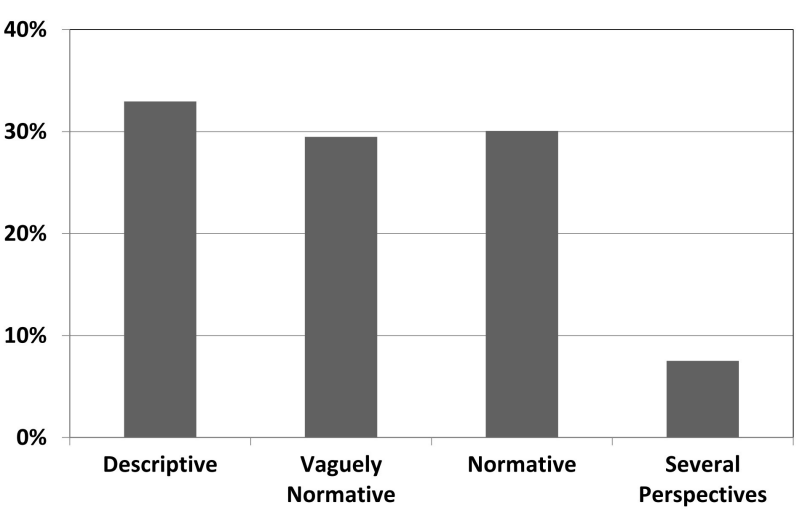

c)

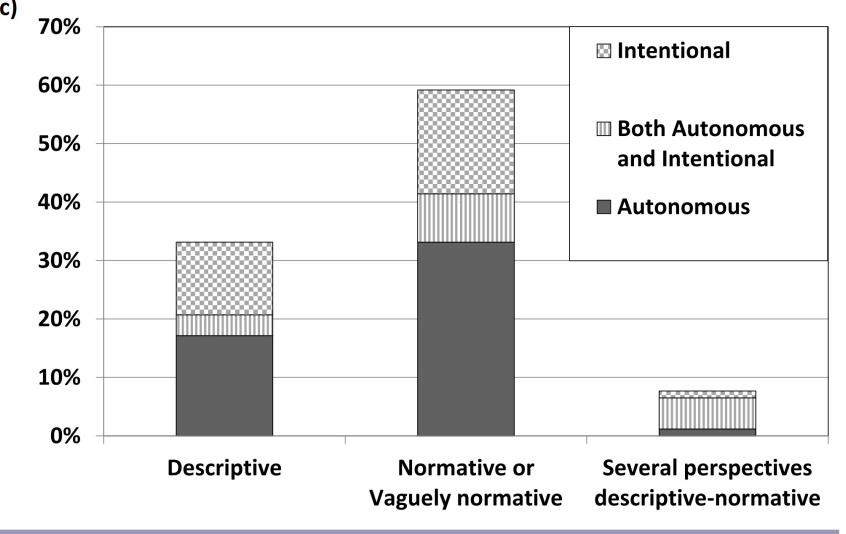

Fig. 3. Share of papers that refer to adaptability according to our four categories (left axis) and total number of papers (right axis). This analysis was based on the first bibliometric search (see Methods).

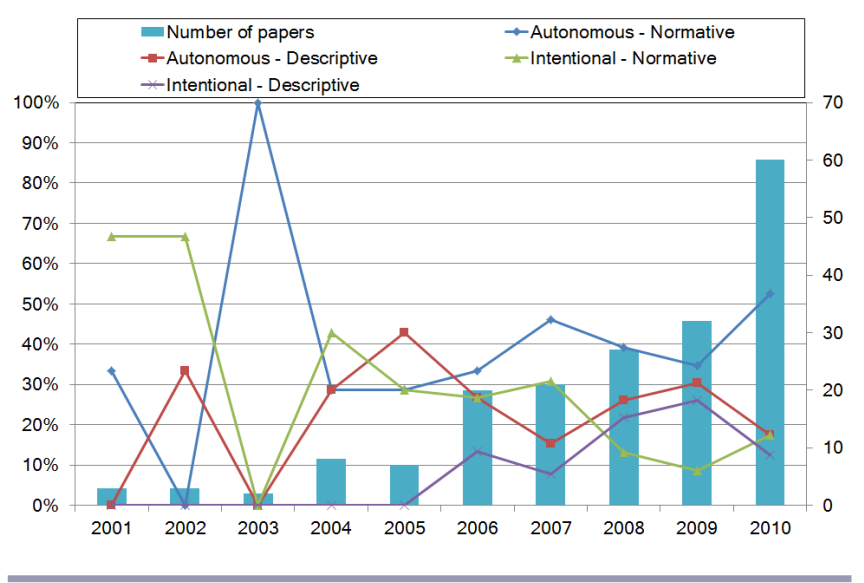

Intentional and normative

In this set of papers ( $18 \%$ of the papers analyzed), the use of adaptability recognizes the need to study people as strategically planning and intentional actors and also gives a norm on what is considered successful adaptive behavior. The key challenge is often described as mainstreaming of lessons learned, or avoiding socially defined negative outcomes. Unlike the normativeautonomous framing, the normative-intentional combination needs not portray adaptability as something positive. The first two citations below provide explicitly normative frameworks, suggesting that intentional adaptations and strategies of local actors are successful. The third suggests that actors can have incentives to adapt, or even increase their adaptive capacity, in a way that decreases social wellbeing (economic efficiency).

In a social-ecological system with high adaptability, the actors have the capacity to sustain the system in desired states in response to changing conditions and disturbance events [...] The second section describes the development of [Ecomuseum Kristianstads Vattenrike] and the selforganization process toward an adaptive co-management system [...] how one local individual played a critical role in leading change and transforming governance into an adaptive co-management system. (Olsson et al. 2004b:2-4)

... because human actions dominate social-ecological systems, the adaptability of such systems is mainly a function of the individuals and groups managing them. Their actions influence resilience, either intentionally or unintentionally (Berkes et al. 2003). Their capacity to manage resilience with intent determines whether they can successfully avoid crossing into an undesirable system regime or succeed in crossing into a desirable one. (Walker et al. 2006b:3)

In both responses involving rule-breaking-on the part of the Forest Department and local people-perverse 
learning results in a positive outcome with respect to the third resilience characteristic, the capacity to learn and adapt [breaking rules]. However, it should be emphasized that the learning is perverse because it benefits few at the expense of many and endangers the forest resource. (Bingeman et al. 2004:111)

\section{Power issues and transformations}

Of the SES resilience literature published in the period 2001-2015, 44 out of 798 papers (less than 6\%) mentioned "power" in the title, abstract, or key words, whereas 198 papers (roughly one in four) mentioned "transform*." Fig. 4 shows the total number of papers per year. It is clear that transformation and power issues are increasingly being addressed in SES literature, at least in absolute terms.

Fig. 4. Total number of papers and number of papers that also mention power and transformation, respectively.

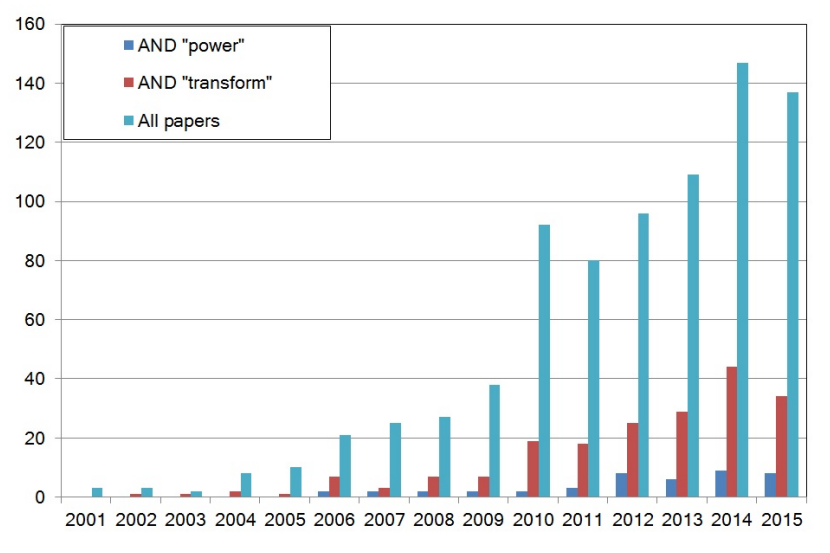

\section{DISCUSSION}

Our results show that the literature on resilience of SES is very diverse when it comes to how adaptability is defined, analyzed, and discussed. Previous studies have concluded that many strands of scholarship discuss adaptive capacity (not only the field of SES research), and they do so differently (e.g., Plummer and Armitage 2010:7-8).

Our results put numbers on this diversity (Fig. 2): $31 \%$ of the assessed papers do address actors with intentions and strategies. An additional $17 \%$ use both intentional and autonomous framings. Thus, we must reject the first hypothesis, that the SES literature treats adaptability as a capacity of a system to selforganize in an autonomous way without describing agency. Similarly, we find that $33 \%$ of the assessed papers use a descriptive framing, and an additional $8 \%$ have several framings. Although a normative use dominates, our results do not support a generalization that adaptability is used normatively in this literature. We can, therefore, also reject the second hypothesis, that SES literature necessarily makes normative judgements concerning what are "desirable" adaptations.

\section{Autonomous or intentional dynamics}

As discussed in the theory section, self-organization may refer to either autonomous or intentional processes. The former is inspired by CAS theory and sees self-organization as an uncoordinated process of adaptations resulting in emerging system properties at higher levels of social organization. This is common in the ecosystem resilience literature but, contrary to assertions by Olsson et al. (2015), the SES literature often describes self-organization as voluntary, intentional decentralized actions.

The papers conceptualizing adaptability as only autonomous $(51 \%)$ did not assess peoples' strategies or social-ecological feedbacks, including learning or organizational/policy change in the context of adaptability, and therefore, did not really address the capacity to adapt. However, these papers seem to have a different purpose, so it may not be accurate to portray them as "failing" to recognize the organizational/political aspects of adaptations. Our impression from the assessed papers is that the analytical focus under study influenced the construction of adaptability: adaptations that appear to be autonomously selforganized in analyses at higher levels of abstraction or when assessing only ecological state and trends (MA 2005a), are instead described as driven by actors with (conflicting) intentions and strategies if another analytical focus is chosen. For example, Walker et al. (2004:1) use an autonomous CAS framing "to diagnose known examples of regional development" like the Kristianstad case, whereas local empirical analyses of the same case focus on intentional actors, networking, and institutions (Olsson et al. 2004b, Hahn et al. 2006, 2008, Johannessen and Hahn 2012).

The CAS framing in much of this literature has other advantages also in the adaptability discourse: in particular, in analyzing the "need" for adaptability in management of SES and types of capacities that will be required if crises cascade across scales and systems. Complex adaptive systems and other systems approaches in SES research enable analysis of anticipated vulnerability related to thresholds, tipping points, and ecological regime shifts (Walker et al. 2009). Such anticipated vulnerabilities are often analyzed within a (vaguely) normative context, assuming that adaptability is good without discussing agency. Although discussing vulnerability reduction in a normative framework may not necessarily be a problem-people can often agree that avoiding famine and drought is good (Duit et al. 2010 - there are cases where famine and food provision are used as political tools (Keller 1992), and in such cases, an autonomous-normative framework is of course not very useful.

There is a huge leap from an analysis of adaptability as "needed" to an analysis of how it is organized by real people (Berkes 2009); whether or not related to a certain desired outcome. Recent literature on social learning and adaptive comanagement opens up the "black box" of self-organization and acknowledges that learning is not value free and that power issues are important parts of the system dynamics in a SES that sometimes block "desirable" adaptations and transformations (e.g., Plummer and Armitage 2007, Armitage et al. 2008, Berkes 2009, Reed et al. 2010, Österblom and Folke 2013, Nykvist 2014). This also holds for social-ecological memories as contributing to adaptability and resilience (Nykvist and von Heland 2014).

Identifying the need for adaptation is one research endeavor, and assessing the capacity to adapt, or the art of adaptation, is another. There seems to be a division of labor between researchers 
with different foci, just like Brand and Jax (2007:10-11) suggest a division of labor between a descriptive use of resilience in ecology (ecosystem resilience) and a "vague and malleable" use of resilience (social-ecological resilience) in transdisciplinary research (see also Folke 2006). Therefore, a transition from ecosystem resilience to social-ecological resilience (the focus for this paper), where adaptability is a part of resilience, can be expected to have some implications for the conceptualization of adaptability. The old (Garrett Hardin) framing of the "Tragedy of the Commons" used a maximum sustainable yield rather than a CAS framing, but like CAS, it tended to overlook the role of intention, communication, and collaboration. Hardin's analysis was "based on an extremely sparse view of the commons"(Ostrom 2007:15183).

Interestingly, the SES literature sometimes combines a CAS framing with agency by opening up the self-organization box and filling it with real people and political action. In the theory section, we exemplified this by the emergence of global governance to combat illegal fishing (Österblom and Folke 2013). In a second example, in an evaluation of adaptive comanagement, Plummer and Armitage (2007:65) used CAS and "the lens of resilience to [analyze] the role of institutions and power." Third, Galaz et al. (2010:371) used CAS theory to assess cascading ecological crises, arguing that the "policy failures that occurred were often not inevitable." Inside the self-organization box of adaptation, they discussed a combination of psychological, bureau-organizational, and political factors that decreased the adaptive capacity. Finally, the panarchy multiscale version of the adaptive cycle (Holling et al. 2002) has been employed by Hahn (2011) to analyze how the social memory at higher institutional levels was used strategically by some actors to change power structures and further develop the biosphere trajectory at the lower municipal level of Kristianstad.

\section{Normative or descriptive positions}

If science is what scientists do, we may conclude that "adaptability" is primarily a normative term in the context of resilience and SES. One-third of the assessed papers used adaptability in an explicitly normative way. Another third used a vaguely normative framing (Fig. 2). However, as 33\% of the papers in this review suggest, it is of course possible to make a descriptive analysis of adaptability, just as democracy and other concepts with normative connotations can be analyzed descriptively. The fact that "maladaptation" is normative (negative) does not necessarily make "adaptation" normative (positive). Although "adaptation" is a more descriptive term in the literature, reflecting its original ecological use (Plummer and Armitage 2010:7), "having a capacity to adapt" appears to have normative connotations, e.g., in relation to capacity building.

A high capacity or ability to adapt is, of course, related to an expected increase in human wellbeing. Still, some caution is warranted. A high adaptability in multistakeholder situations characterized by genuine uncertainty, wicked problems (Ludwig 2001), or postnormal science (Funtowicz and Ravetz 1992) may result in lowering human wellbeing ex post. And perverse learning, perverse incentives, and economic rent-seeking may also coexist with high adaptability and result in lower human wellbeing overall (see citation above by Bingeman et al. 2004). Thus, adaptability should not be equated with a sustainable, or any other, outcome. Similarly, stakeholder participation cannot be assumed to be a suitable and/or sufficient method to achieve social learning in the sense of deeper learning among a range of actors (Elbakidze et al. 2013, Nykvist 2014). And social learning in turn should not be equated with proenvironmental or sustainable behavior or other desirable outcome (Reed et al. 2010).

As mentioned before, even if there is normative agreement on goals, such as the UN's announcement of its Sustainable Development Goal as the new global consensus, we should expect conflicting interests when policies are formulated for adaptations and transformations to meet these goals. Words like "desirable" should either be avoided in SES resilience literature or be conditional on the identification of an explicit normative framework or specific actors. Following this reasoning, adaptability could be defined as the capacity of actors to change ecosystem management and thereby avoid what they regard as undesirable regime shifts. Transformability could be defined nonnormatively as the capacity to break path dependency and shift toward a new development trajectory justified by a fundamentally different narrative.

\section{Pluralism in social science}

We found little support for associating the SES literature to the conservative social equilibrium ideas of sociological functionalism and its "inability to explain rapid social change" (Olsson et al. 2015:5). In fact, during the last decades, systems approaches like complexity theory have provided diversity and promising approaches in social science (Byrne 1998, Urry 2003, Castellani and Hafferty 2009). For example, Schwandt and Szabla (2003) identify a conceptual congruence between Giddens' structure and agency theory and complexity theory, and CAS has also inspired anthropology (Lansing 2003).

Our review of the 183 papers indicates that complexity theory and CAS can be applied to the issue of adaptation in many different ways; our categorization shows that it provides pluralism. Pluralism is ironically what Olsson et al. (2015:9) also advocate while they dismiss the resilience approach, which they argue is "rooted in complexity theory" and functionalism and therefore "becomes the equivalent of stability and harmony" (Olsson et al. 2015:5).

The alleged assumption of harmonious consensus building requires reflection on the intentional-normative framing: that people are described as having intentionality and seeking common interests. An insight from social science, prominent in the critiques of resilience, is that harmony and consensus can never be assumed, not even on knowledge. Adaptability of SES has been defined as the capacity to adapt and respond to change "in an informed manner" (Folke 2006). This raises the question of whose knowledge should count, or which knowledge systems (local, indigenous, or scientific) and strategies qualify as more or less "informed."

Consider two adaptive strategies proposed to feed the poor and achieve the second Sustainable Development Goal (Zero Hunger): agroecology and genetically modified organisms (GMO). Pretty et al. (2006) and an international report (United Nations 2011) have suggested agroecology as a promising strategy to adapt or transform agriculture in low-income countries to enhance yields sustainably. Other actors have suggested input 
subsidies to GMOs and another "green revolution" for the same purpose (Huang et al. 2002, Carpenter 2010). These two different strategies reflect different worldviews and priorities held by different stakeholders. They are both supported by scientific research and thus ecologically "informed." They are both "desirable" within their respective political and scientific frameworks, and from an analytical perspective, both manifest adaptive capacity.

The ultimate normative challenge concerns claims for efficiency, which means connecting a particular adaptation or transformation strategy to desirable outcomes. The agricultural example above suggests that both ex ante and ex post evaluations of such strategies (e.g., what is efficient and desirable for whom?) sometimes belong to the political struggle of establishing the (scientific) truth.

\section{CONCLUSION}

We conclude by emphasizing the plurality of approaches in the research on resilience and SES. There are signs that ontological clashes between social sciences and SES research have resulted in constructive pathways for dealing with questions of adaptation and adaptability, drawing on core concepts and insights "from both sides." Rather than assuming consensus and selforganization, resilience in SES has been employed empirically to explain how social learning and networking are used to alter power structures and achieve adaptations and transformations. We believe this constructive debate needs to continue to advance science and provide adequate policy support for sustainability transformations.

Responses to this article can be read online at: http://www.ecologyandsociety.org/issues/responses. $\mathrm{php} / 9026$

\section{Acknowledgments:}

We would like to thank Ryan Plummer for comments on a previous version of this paper, as well as Sarah Cornell and Jamila Haider for proofreading. This research was financed by the Swedish Research Council Formas, through the projects EKOKLIM and SAPES, and the Swedish Foundation for Strategic Environmental Research (Mistra), through the project Mistra Financial Systems (MFS), and a core grant to the Stockholm Resilience Centre.

\section{LITERATURE CITED}

Adger, W. N. 2006. Vulnerability. Global Environmental Change 16:268-281. http://dx.doi.org/10.1016/j.gloenvcha.2006.02.006

Armitage, D., M. Marshcke, and R. Plummer. 2008. Adaptive comanagement and the paradox of learning. Global Environmental Change 18:86-98. http://dx.doi.org/10.1016/j.gloenvcha.2007.07.002

Baral, N., M. Stern, and J. T. Heinen. 2010. Growth, collapse, and reorganization of the Annapurna Conservation Area, Nepal: an analysis of institutional resilience. Ecology and Society 15(3):14.

Berkes, F. 2009. Evolution of co-management: Role of knowledge generation, bridging organizations and social learning. Journal of
Environmental Management 90(5):1692-1702. http://dx.doi. org/10.1016/j.jenvman.2008.12.001

Berkes, F., J. Colding, and C. Folke. 2003. Navigating Socialecological systems: building resilience for complexity and change. Cambridge University Press, New York, New York, USA. http:// dx.doi.org/10.1017/cbo9780511541957

Berkes, F., and C. Folke. 1998. Linking social and ecological systems: management practices and social mechanisms for building resilience. Cambridge University Press, Cambridge, UK.

Bingeman, K., F. Berkes, and J. S. Gardner. 2004. Institutional responses to development pressures: resilience of socialecological systems in Himachal Pradesh, India. International Journal of Sustainable Development and World Ecology 11:99-115. http://dx.doi.org/10.1080/13504500409469815

Blackmore, J. M., and R. A. J. Plant. 2008. Risk and resilience to enhance sustainability with application to urban water systems. Journal of Water Resources Planning and Management 134 (3):224-233. http://dx.doi.org/10.1061/(asce)0733-9496(2008)134:3 (224)

Bodin, O., and J. Norberg. 2005. Information network topologies for enhanced local adaptive management. Environmental Management 35:175-193. http://dx.doi.org/10.1007/s00267-004-0036-7

Brand, F. S., and K. Jax. 2007. Focusing the meaning(s) of resilience: resilience as a descriptive concept and a boundary object. Ecology and Society 12(1):23. http://dx.doi.org/10.5751/ es-02029-120123

Bromley, D. W. 1990. The ideology of efficiency: searching for a theory of policy analysis. Journal of Environmental Economics and Management 19:86-107. http://dx.doi.org/10.1016/0095-0696 (90)90062-4

Bromley, D. W. 1998. Searching for sustainability: the poverty of autonomous order. Ecological Economics 24:231-240. http://dx. doi.org/10.1016/S0921-8009(97)00145-6

Brown, K. 2011. Sustainable adaptation: an oxymoron? Climate and Development 3:21-31. http://dx.doi.org/https://doi.org/10.3763/ cdev.2010.0062

Brown, K. 2014. Global environmental change I: a social turn for resilience? Progress in Human Geography 38:107-117. http://dx. doi.org/https://doi.org/10.1177/0309132513498837

Byrne, D. 1998. Complexity theory and the social sciences: an introduction. Routledge, London, UK.

Carpenter, J. E. 2010. Peer-reviewed surveys indicate positive impact of commercialised GM crops. Nature Biotechnology 28:319-321. http://dx.doi.org/10.1038/nbt0410-319

Castellani, B., and F. W. Hafferty. 2009. Sociology and complexity science: a new field of inquiry. Springer, Berlin/Heidelberg, Germany. http://dx.doi.org/10.1007/978-3-540-88462-0

Cote, M., and A. J. Nightingale. 2012. Resilience thinking meets social theory: situating social change in socio-ecological systems (SES) research. Progress in Human Geography 36(4):475-489. http://dx.doi.org/10.1177/0309132511425708

Crona, B. I., and J. N. Parker. 2012. Learning in support of governance: theories, methods, and a framework to assess how 
bridging organizations contribute to adaptive resource governance. Ecology and Society 17(1):32. http://dx.doi. org/10.5751/es-04534-170132

Duit, A., V. Galaz, K. Eckerberg, and J. Ebbesson. 2010. Governance, complexity, and resilience: introduction. Global Environmental Change-Human and Policy Dimensions 20:363368. http://dx.doi.org/10.1016/j.gloenvcha.2010.04.006

Elbakidze, M., T. Hahn, V. Mauerhofer, P. Angelstam, and R. Axelsson. 2013. Legal framework for biosphere reserves as learning sites for sustainable development: a comparative analysis of Ukraine and Sweden. Ambio 42:174-187. http://dx.doi. org/10.1007/s13280-012-0373-3

Fink, A. 2005. Conducting research literature reviews: from the internet to paper. Second edition. Sage Publications, Thousand Oaks, California, USA.

Fischer, J., T. A. Gardner, E. M. Bennett, P. Balvanera, R. Biggs, S. Carpenter, T. Daw, C. Folke, R. Hill, T. P. Hughes, et al. 2015. Advancing sustainability through mainstreaming a socialecological systems perspective. Current Opinion in Environmental Sustainability 14:144-149. http://dx.doi.org/10.1016/j.cosust.2015.06.002

Folke, C. 2006. Resilience: the emergence of a perspective for socio-ecological systems analyses. Global Environmental Change 16:253-267. http://dx.doi.org/10.1016/j.gloenvcha.2006.04.002

Folke, C., S. Carpenter, B. Walker, M. Scheffer, T. Chapin, and J. Rockström. 2010. Resilience thinking: integrating resilience, adaptability and transformability. Ecology and Society 15(4):20.

Folke, C., T. Hahn, P. Olsson, and J. Norberg. 2005. Adaptive governance of social-ecological systems. Annual Review of Environment and Resources 30:441-473. http://dx.doi.org/10.1146/ annurev.energy.30.050504.144511

Funtowicz, S. O., and J. Ravetz. 1992. Three types of risk assessment and the emergence of post-normal science. Pages 251273 in S. O. Funtowicz and J. Ravetz, editors. Social theories of risk. Praeger, London, UK.

Galaz, V. 2005. Social-ecological resilience and social conflict: institutions and strategic adaptation in Swedish water management. AMBIO: A Journal of the Human Environment 34:567-572. http://dx.doi.org/10.1579/0044-7447-34.7.567

Galaz, V., F. Moberg, E. Olsson, E. Paglia, and C. Parker. 2010. Institutional and political leadership dimensions of cascading ecological crises. Public Administration 89:361-380. http://dx.doi. org/10.1111/j.1467-9299.2010.01883.x

Gallopin, G. C. 2006. Linkages between vulnerability, resilience, and adaptive capacity. Global Environmental Change 16:293-303. http://dx.doi.org/10.1016/j.gloenvcha.2006.02.004

Hahn, T. 2011. Self-organized governance networks for ecosystem management: who is accountable? Ecology and Society 16(2):18. http://dx.doi.org/https://doi.org/10.5751/ES-04043-160218

Hahn, T., P. Olsson, C. Folke, and K. Johansson. 2006. Trustbuilding, knowledge generation and organizational innovations: the role of a bridging organization for adaptive co-management of a wetland landscape around Kristianstad, Sweden. Human Ecology 34:573-592. http://dx.doi.org/10.1007/s10745-006-9035$\underline{\mathrm{z}}$
Hahn, T., L. Schultz, C. Folke, and P. Olsson. 2008. Social networks as sources of resilience in social-ecological systems. Pages 119-148 in J. Norberg and G. Cumming, editors. Complexity theory for a sustainable future. Columbia University Press, New York, New York, USA; Chichester, West Sussex, UK.

Hatt, K. 2012. Social attractors: a proposal to enhance "resilience thinking" about the social. Society and Natural Resources 26 (1):30-43. http://dx.doi.org/10.1080/08941920.2012.695859

Hayek, F. 2012. Law, legislation and liberty: a new statement of the liberal principles of justice and political economy. Routledge, Abingdon, UK.

Holling, C. S. 2001. Understanding the complexity of economic, ecological, and social systems. Ecosystems 4:390-405. http://dx. doi.org/10.1007/s10021-001-0101-5

Holling, C. S., L. H. Gunderson, and G. D. Peterson. 2002. Sustainability and panarchies. Pages 63-102 in C. S. Holling and L. H. Gunderson, editors. Panarchy: understanding transformations in human and natural systems. Island Press, Washington, D.C., USA.

Hornborg, A. 2009. Zero-sum world: challenges in conceptualizing environmental load displacement and ecologically unequal exchange in the world-system. International Journal of Comparative Sociology 50:237-262. http://dx.doi. org/10.1177/0020715209105141

Huang, J., C. Pray, and S. Rozelle. 2002. Enhancing the crops to feed the poor. Nature 418:678-684. http://dx.doi.org/10.1038/ nature 01015

Johannessen, Å., and T. Hahn. 2012. Social learning towards a more adaptive paradigm? Reducing flood risk in Kristianstad municipality, Sweden. Global Environmental Change 23(1):372381. http://dx.doi.org/10.1016/j.gloenvcha.2012.07.009

Keller, E. J. 1992. Drought, war, and the politics of famine in Ethiopia and Eritrea. Journal of Modern African Studies 30:609609. http://dx.doi.org/10.1017/S0022278X00011071

Klijn, E.-H., and C. Skelcher. 2007. Democracy and governance networks: compatible or not? Public Administration 85(3):587608. http://dx.doi.org/https://doi.org/10.1111/j.1467-9299.2007.00662. $\underline{\mathrm{x}}$

Lackey, R. T. 2001. Values, policy, and ecosystem health. BioScience 51:437-443. http://dx.doi.org/10.1641/0006-3568 (2001)051[0437:VPAEH]2.0.CO;2

Lansing, J. S. 2003. Complex adaptive systems. Annual Review Anthropology 32:183-204. http://dx.doi.org/10.1146/annurev. anthro.32.061002.093440

Leach, M. 2008. Pathways to sustainability in the forest? Misunderstood dynamics and the negotiation of knowledge, power, and policy. Environment and Planning A 40:1783-1795. http://dx.doi.org/10.1068/a40215

Levin, S. A. 1998. Ecosystems and the biosphere as complex adaptive systems. Ecosystems 1:431-436. http://dx.doi.org/10.1007/ $\underline{\mathrm{s} 100219900037}$ 
Levin, S. 1999. Fragile dominion. Perseus Publishing, Cambridge, Massachusetts, USA.

Ludwig, D. 2001. The era of management is over. Ecosystems 4:758-764. http://dx.doi.org/10.1007/s10021-001-0044-x

MacKinnon, D., and K. D. Derickson. 2013. From resilience to resourcefulness: a critique of resilience policy and activism. Progress in Human Geography 37(2):253-270. http://dx.doi. org/10.1177/0309132512454775

Millennium Ecosystem Assessment. 2005a. The millennium ecosystem assessment, ecosystems and human well-being: current state and trends. Island Press, Washington D.C., USA.

Millennium Ecosystem Assessment. 2005b. The millennium ecosystem assessment, ecosystems and human well-being: synthesis. Island Press, Washington, D.C., USA.

Nelson, D., N. Adger, and K. Brown. 2007. Adaptation to environmental change: contributions of a resilience framework. Annual Review of Environmental Resources 32:395-419. http://dx. doi.org/10.1146/annurev.energy.32.051807.090348

Nykvist, B. 2012. Social learning in the Anthropocene. Dissertation in Natural Resources Management. Stockholm University, Stockholm, Sweden.

Nykvist, B. 2014. Does social learning lead to better natural resource management? A case study of the modern farming community of practice in Sweden. Society and Natural Resources 27(4):436-450. http://dx.doi.org/10.1080/08941920.2013.861562

Nykvist, B., and J. von Heland. 2014. Social-ecological memory as a source of general and specified resilience. Ecology and Society 19(2):47. http://dx.doi.org/10.5751/es-06167-190247

O'Brien, K., B. Hayward, and F. Berkes. 2009. Rethinking social contracts: building resilience in a changing climate. Ecology and Society 14(2):12. http://dx.doi.org/10.5751/es-03027-140212

Olsson, P., C. Folke, and F. Berkes. 2004a. Adaptive comanagement for building resilience in social-ecological systems. Environmental Management 34:75-90. http://dx.doi.org/ https://doi.org/10.1007/s00267-003-0101-7

Olsson, P., C. Folke, and T. Hahn. 2004b. Social-ecological transformations for ecosystem management: the development of adaptive co-management of a wetland landscape in southern Sweden. Ecology and Society 9(4):2. http://dx.doi.org/https://doi. org/10.5751/ES-00683-090402

Olsson, P., C. Folke, and T. P. Hughes. 2008. Navigating the transition to ecosystem-based management of the Great Barrier Reef, Australia. Proceedings of the National Academy of Sciences 105(28):9489-9494. http://dx.doi.org/10.1073/pnas.0706905105

Olsson, P., V. Galaz, and W. J. Boonstra. 2014. Sustainability transformations: a resilience perspective. Ecology and Society 19 (4):1. http://dx.doi.org/10.5751/es-06799-190401

Olsson, P., L. H. Gunderson, S. R. Carpenter, P. Ryan, L. Lebel, C. Folke, and C. S. Holling. 2006. Shooting the rapids: navigating transitions to adaptive governance of social-ecological systems. Ecology and Society 11(1):18. http://dx.doi.org/10.5751/ $\underline{\text { es-01595-110118 }}$
Olsson, L., A. Jerneck, H. Thoren, J. Persson, and D. O’Byrne. 2015. Why resilience is unappealing to social science: theoretical and empirical investigations of the scientific use of resilience. Science Advances 1(4):e1400217. http://dx.doi.org/10.1126/ sciadv. 1400217

Österblom, H., and C. Folke. 2013. Emergence of global adaptive governance for stewardship of regional marine resources. Ecology and Society 18(2):4. http://dx.doi.org/10.5751/es-05373-180204

Österblom, H., and U. R. Sumaila. 2011. Toothfish crises, actor diversity and the emergence of compliance mechanisms in the Southern Ocean. Global Environmental Change 21(3):972-982. http://dx.doi.org/10.1016/j.gloenvcha.2011.04.013

Ostrom, E. 2007. A diagnostic approach for going beyond panaceas. Proceedings of the National Academy of Sciences 104 (39):15181-15187. http://dx.doi.org/10.1073/pnas.0702288104

Ostrom, W., J. Burger, C. B. Field, R. B. Norgaard, and D. Policansky. 1999. Revisiting the commons: local lessons, global challenges. Science 284(5412):278-282. http://dx.doi.org/10.1126/ science. 284.5412 .278

Petticrew, M., and H. Roberts. 2006. Systematic reviews in the social sciences. Blackwell Publishing, Malden, Massachusetts, USA; Oxford, UK: Victoria, Australia. http://dx.doi. org/10.1002/9780470754887

Plummer, R., and D. Armitage. 2007. A resilience-based framework from evaluating adaptive co-management: linking ecology, economics and society in a complex world. Ecological Economics 61(1):62-74. http://dx.doi.org/https://doi.org/10.1016/ j.ecolecon.2006.09.025

Plummer, R., and D. R. Armitage. 2010. Integrating perspectives on adaptive capacity and environmental governance. Pages 1-19 in R. Plummer and D. R. Armitage, editors. Adaptive capacity and environmental governance. Springer, New York, New York, USA. http://dx.doi.org/10.1007/978-3-642-12194-4 1

Pretty, J., A. Noble, D. Bossio, J. Dixon, R. E. Hine, F. W. T. Penning de Vries, and J. I. L. Morison. 2006. Resource-conserving agriculture increases yields in developing countries. Environmental Science and Technology 40(4):1114-1119. http://dx.doi. org/10.1021/es051670d

Reed, M. S., A. C. Evely, G. Cundill, I. Fazey, J. Glass, A. Laing, J. Newig, B. Parrish, C. Prell, C. Raymond, and L. C. Stringer. 2010. What is social learning? Ecology and Society 15(4): r1.

Robards, M. D., M. L. Schoon, C. L. Meek, and N. L. Engle. 2011. The importance of social drivers in the resilient provision of ecosystem services. Global Environmental Change 21(2):522529. http://dx.doi.org/10.1016/j.gloenvcha.2010.12.004

Rudberg, P. M., M. Escobar, J. Gantenbein, and N. Niiro. 2015. Mitigating the adverse effects of hydropower projects: a comparative review of river restoration and hydropower regulation in Sweden and the United States. The Georgetown International Environmental Law Review 27:251-273

Schwandt, D. R., and D. B. Szabla. 2013. Structuration theories and complex adaptive social systems: inroads to describing human interaction dynamics. Emergence: Complexity and Organization 15(4):1-20. 
Smit, B., and J. Wandel. 2006. Adaptation, adaptive capacity and vulnerability. Global Environmental Change 16(3):282-292. http:// dx.doi.org/10.1016/i.gloenvcha.2006.03.008

Steffen, W., K. Richardson, J. Rockström, S. E. Cornell, I. Fetzer, E. M. Bennett, R. Biggs, S. R. Carpenter, W. de Vries, and C. A. de Wit. 2015. Planetary boundaries: guiding human development on a changing planet. Science 347(6223):1259855. http://dx.doi. org/10.1126/science. 1259855

United Nations. 2011. Report submitted by the Special Rapporteur on the right to food, Olivier De Schutter. [online] URL: http://www. srfood.org/en/report-agroecology-and-the-right-to-food

United Nations. 2015. Consensus reached on new sustainable development agenda to be adopted by world leaders in September. [online] URL: http://www.un.org/sustainabledevelopment/blog/2015/08/ transforming-our-world-document-adoption/

Urry, J. 2003. Global complexity. Polity Press, Cambridge/Oxford, UK.

Vetter, S. 2009. Drought, change and resilience in South Africa's arid and semi-arid rangelands. South African Journal of Science 105:29-33.

Walker, B., N. Abel, J. Anderies, and P. Ryan. 2009. Resilience, adaptability, and transformability in the Goulburn-Broken Catchment, Australia. Ecology and Society 14(1):12. http://dx. doi.org/10.5751/es-02824-140112

Walker, B., J. Anderies, A. Kinzig, and P. Ryan. 2006a. Exploring resilience in social-ecological systems through comparative studies and theory development: introduction to the special issue. Ecology and Society 11(1):12. http://dx.doi.org/https://doi. org/10.5751/ES-01573-110112

Walker, B., L. Gunderson, A. Kinzig, C. Folke, S. Carpenter, and L. Schultz. 2006b. A handful of heuristics and some propositions for understanding resilience in social-ecological systems. Ecology and Society 11(1):13. http://dx.doi.org/https://doi.org/10.5751/ ES-01530-110113

Walker, B., C. S. Holling, S. R. Carpenter, and A. Kinzig. 2004. Resilience, adaptability and transformability in social-ecological systems. Ecology and Society 9(2):5. http://dx.doi.org/10.5751/ es-00650-090205

Westley, F. 2002. The devil in the dynamics: adaptive management on the front lines. Pages 333-360 in L. H. Gunderson and C. S. Holling, editors. Panarchy: understanding transformations in human and natural systems. Island Press, Washington, D.C., USA.

Westley, F., S. R. Carpenter, W. A. Brock, C. S. Holling, and L. Gunderson. 2002. Why systems of people and nature are not just social and ecological systems. Pages 103-119 in L. H. Gunderson and C. S. Holling, editors. Panarchy: understanding transformation in human and natural systems. Island Press, Washington, D.C., USA.

Westley, F. R., O. Tjornbo, L. Schultz, P. Olsson, C. Folke, B. Crona, and Ö. Bodin. 2013. A theory of transformative agency in linked social-ecological systems. Ecology and Society 18:27. http://dx.doi.org/10.5751/es-05072-180327 


\section{Appendix}

Table A1. Twelve examples of coding.

\begin{tabular}{|c|c|c|c|c|c|}
\hline Reference & Important statements & $\begin{array}{l}\text { Assessment Q1 } \\
\text { Spontaneous(S) vs. } \\
\text { Intentional(I) } \\
\text { (B indicates Both) }\end{array}$ & & $\begin{array}{l}\text { Assessment Q2 } \\
\text { Descriptive(D) vs. } \\
\text { Normative(N)/Vaguely } \\
\text { Normative(VN) } \\
\text { (SP indicates Several } \\
\text { Perspectives) } \\
\end{array}$ & \\
\hline $\begin{array}{l}\text { Berkes } \\
(2010)\end{array}$ & $\begin{array}{l}\text { p. } 495 \text { Hence, successive loops of learning-as-participation help combine elements of adaptive } \\
\text { management with elements of co-management. Each cycle starts with observation and identification of } \\
\text { problems and opportunities, leading to action-reflection and further action. Outcomes of successive plans } \\
\text { need to be monitored and evaluated, followed by reflection, to lead to the next cycle. Each cycle provides } \\
\text { new information for the next iteration, and also serves as a learning step, leading to co-management at } \\
\text { successively larger scales over time (Berkes 2009). }\end{array}$ & $\begin{array}{l}\text { No reference to intentions } \\
\text { or strategies. Loops of } \\
\text { learning are assumed to } \\
\text { emerge to co- } \\
\text { management. }\end{array}$ & S & $\begin{array}{l}\text { No particular system } \\
\text { state or desirable end is } \\
\text { referred to. The process } \\
\text { of adaptive co- } \\
\text { management is } \\
\text { discussed descriptively. }\end{array}$ & D \\
\hline $\begin{array}{l}\text { Allison and } \\
\text { Hobbs } \\
(2004)\end{array}$ & $\begin{array}{l}\text { p. } 5 \text { If each of the three properties (potential, connectedness, and resilience) in the adaptive cycle is given } \\
\text { two nominal levels, either low or high, then the adaptive cycle model uses only four of a possible eight } \\
\text { combinations (23) of the three properties, and two of the other four combinations are suggested as } \\
\text { pathological states, labeled the poverty trap and the rigidity trap by Holling et al. (2002c), which are } \\
\text { departures from the adaptive cycle (Fig. 3). }\end{array}$ & $\begin{array}{l}\text { No discussion of } \\
\text { strategies of actors, all } \\
\text { events are just unfolding. }\end{array}$ & S & $\begin{array}{l}\text { Adaptive cycle has } \\
\text { pathological states that } \\
\text { are less desirable, but no } \\
\text { clear definitions of what } \\
\text { these states are. Vaguely } \\
\text { normative. }\end{array}$ & $\mathrm{VN}$ \\
\hline $\begin{array}{l}\text { Barthel et } \\
\text { al. (2005) }\end{array}$ & $\begin{array}{l}\text { p.16: need to develop a social capacity for urban ecosystem management to respond to change, and to } \\
\text { develop policy directions that can help build resilience to deal with further change. Berkes et al. (2003) refer } \\
\text { to such a capacity as "adaptive capacity." } \\
\text { p.16: A crucial part of building adaptive capacity is a governance system that can learn from experience and } \\
\text { generate knowledge across organizational levels. } \\
\text { p. 2: Finally, we discuss how their integration in adaptive co-management systems may provide more } \\
\text { efficient management of biodiversity and ecosystem services in the NUP.... investigate how adaptive } \\
\text { capacity can be built to better respond to social-ecological change }\end{array}$ & $\begin{array}{l}\text { Building adaptive } \\
\text { capacity requires } \\
\text { governance and learning } \\
\text { from experience, } \\
\text { generating knowledge } \\
\text { across organizational } \\
\text { levels. No discussions of } \\
\text { strategies or agendas. } \\
\end{array}$ & S & \begin{tabular}{l|} 
Adaptive co-management \\
tied to more efficient \\
management of \\
biodiversity and \\
ecosystem services \\
enabling better responses \\
to social-ecological \\
change
\end{tabular} & $\mathrm{N}$ \\
\hline $\begin{array}{l}\text { Schluter et } \\
\text { al. (2009) }\end{array}$ & $\begin{array}{l}\text { p } 497 \text { A farmer bases his labor allocation decision on an evaluation of the returns per effort obtained from } \\
\text { his farming and fishing activities in the previous year. Hence, he adapts his strategy by learning from past } \\
\text { experiences to find the mixture of activities that yields the highest returns per effort. } \\
\text { p } 501 \text { This learning process and its transient dynamics can lead to suboptimal outcomes when agents do } \\
\text { not have enough time or capital to adapt their strategy to the local conditions before going bankrupt. } \\
\text { Diversification of water use by balancing the needs of different water users as demonstrated here can } \\
\text { contribute to an enhancement of adaptive capacity and thus resilience. }\end{array}$ & $\begin{array}{l}\text { Farmers are assumed to } \\
\text { spontaneously learn from } \\
\text { experience on a single } \\
\text { parameter (yield). No } \\
\text { analysis of actors } \\
\text { strategies or agendas. } \\
\text { Agents are predictable. }\end{array}$ & S & $\begin{array}{l}\text { Several: both descriptive } \\
\text { in terms of actors } \\
\text { adaptations in the model } \\
\text { studied; and vaguely } \\
\text { normative, in terms of the } \\
\text { overarching frame of } \\
\text { enhancing resilience; and } \\
\text { normative connotations to } \\
\text { suboptimal outcomes. }\end{array}$ & SP \\
\hline
\end{tabular}




\begin{tabular}{|c|c|c|c|c|c|}
\hline $\begin{array}{l}\text { Atwell et al. } \\
\text { (2010) }\end{array}$ & $\begin{array}{l}\text { p. 1083. Resilience is not a normative term; system configurations characterized as resilient may be either } \\
\text { desirable or undesirable. In particular, resilience theorists are interested in understanding where resilience, } \\
\text { adaptive capacity, and the potential for innovation reside in linked social-ecological systems and how these } \\
\text { attributes can be gained, lost, or preserved (Walker et al., 2002). } \\
\text { p. 1083. In this type of trap, which has been referred to as the rigidity trap by resilience theorists } \\
\text { (Gunderson and Holling, 2002; Allison and Hobbes, 2004; Atwell et al., 2009b), the high adaptive potential } \\
\text { and connectedness of social actors makes it possible to continue to invest in the current way of doing } \\
\text { agriculture, in spite of the mounting social and ecological deficits and economic inefficiencies (Harvey, } \\
\text { 2004), associated with this trajectory. } \\
\text { p. 1087. Our participants indicated that regional coordination of scientific monitoring, adaptive management, } \\
\text { and enforceable environmental standards are foundational to long term,multi-objective change given the } \\
\text { complexity of the Corn Belt system. While such an approach was seen by our workshop participants as } \\
\text { having the potential to link agricultural and conservation objectives, they also indicated that macro-scale } \\
\text { programs intended to mandate or coerce landscape change across private property boundaries are often } \\
\text { resisted by stakeholder groups." }\end{array}$ & $\begin{array}{l}\text { Clear discussions of } \\
\text { different actors and } \\
\text { interest of different } \\
\text { groups }\end{array}$ & 1 & $\begin{array}{l}\text { Resilience, and adaptive } \\
\text { capacity, clearly seen as } \\
\text { descriptive concepts. }\end{array}$ & $D$ \\
\hline $\begin{array}{l}\text { Armitage et } \\
\text { al. (2008) }\end{array}$ & $\begin{array}{l}\text { p. 89. Woodhill (2002) considers social learning to be a "process by which society democratically adapts its } \\
\text { core institutions to cope with social and ecological change in ways that will optimize the collective wellbeing } \\
\text { of current and future generations". } \\
\text { p. } 91 \text {. In principle, the core of this learning-by-doing or 'adaptive management' approach involves flexible } \\
\text { institutional and organizational arrangements that encourage reflection and innovative responses (e.g., } \\
\text { modifying resource management strategies in the face of change). } \\
\text { p. } 93 \text {. foster more adaptive forms of co-management may require strategic combinations of various } \\
\text { experimental approaches (from both the natural and social sciences) to enable diverse learning outcomes. } \\
\text { p. 92. 'where there is evidence of ongoing or continuous social learning, then social capital may be } \\
\text { produced and/or increased, and a group or network may } \\
\text { be open to new ideas and adaptive' ... highlight the importance of structured experimentation as a basis to } \\
\text { foster more adaptive forms of co-management. } \\
\text { p. } 93 \text {. The participatory nature of adaptive co-management creates ideal conditions for } \\
\text { collaboration required to support different learning strategies and enable different types of learning.... A } \\
\text { potential strength of adaptive co-management is that it links groups and fosters knowledge synthesis }\end{array}$ & $\begin{array}{l}\text { Adaptive management } \\
\text { refers to reflexive } \\
\text { arrangements by a group } \\
\text { or network with regard to } \\
\text { modify resource } \\
\text { management strategies. } \\
\text { Strategies of actors are } \\
\text { thus considered. } \\
\text { (Detta exempel visar hur } \\
\text { svårt det kan bli för } \\
\text { egentligen diskuterar de } \\
\text { inte intentioner eller } \\
\text { strategier explicit, men } \\
\text { aktörer framställs som } \\
\text { reflexiva vilket är vårt } \\
\text { tredje krav }\end{array}$ & 1 & $\begin{array}{l}\text { Adaptability linked to } \\
\text { social learning which is } \\
\text { framed as desirable, } \\
\text { optimizing collective } \\
\text { wellbeing for future } \\
\text { generations }\end{array}$ & VN \\
\hline $\begin{array}{l}\text { Beier et al. } \\
(2009)\end{array}$ & $\begin{array}{l}\text { p. 9. Tongass system became rigid and maladaptive in response to a confluence of events that fostered } \\
\text { simultaneous collapse dynamics in the policy and economic subsystems. Within } 5 \text { years of the passage of } \\
\text { the TTRA, Tongass timber production declined by roughly } 85 \% \text { and stabilized at an output level } \\
\text { equivalent to the pre-industrial production level (Fig. 1). } \\
\text { p. } 11 \text {. The preceding narrative suggests the importance of changes in federal policy and larger-scale } \\
\text { economic factors as the key drivers of adaptive-cycle dynamics in Tongass governance. Policy } \\
\text { mobilized much of the initial growth, provided much of the stability during the conservation phase, and } \\
\text { served to destabilize-at first incrementally and then rather suddenly-the industrial forestry regime of } \\
\text { the Tongass. } \\
\text { p. } 13 \text {. In the current state, Tongass managers are pitted between environmental } \\
\text { advocacy groups (via litigation and appeals) and pro-timber legislators and executive officials (via } \\
\text { budgets and national leadership). This situation acts to maintain day-to-day Tongass decision making in a } \\
\text { highly stable but inflexible state that constrains managers from responding adaptively to changing } \\
\text { conditions and, ultimately, from finding a sustainable direction for the future governance of the } \\
\text { Tongass. As long as the dominant venues of stakeholder input in Tongass decision making are } \\
\text { adversarial-i.e., through appeals and litigation- the institutional subsystem will remain "trapped" in the } \\
\text { collapse }[\Omega] \text { phase }\end{array}$ & $\begin{array}{l}\text { Narrative draws on } \\
\text { adaptive cycles, but } \\
\text { results are clearly } \\
\text { discussed in context of } \\
\text { strategies of actors, and } \\
\text { of policy making. }\end{array}$ & 1 & $\begin{array}{l}\text { Maladaptive response } \\
\text { equated with } \\
\text { decline/collapse of } \\
\text { forestry system. } \\
\text { Inflexibility constrains } \\
\text { adaptive responses and } \\
\text { ultimately sustainability. }\end{array}$ & $\mathrm{N}$ \\
\hline
\end{tabular}




\begin{tabular}{|c|c|c|c|c|c|}
\hline $\begin{array}{l}\text { Adger } \\
(2006)\end{array}$ & $\begin{array}{l}\text { p. 277. As a result, adaptive actions often reduce the vulnerability of those best placed to take advantage of } \\
\text { governance institutions, rather than reduce the vulnerability of the marginalized, or the undervalued parts of } \\
\text { the social-ecological system (Adger et al., 2005a). } \\
\text { p. } 277 \text {. Adaptation does not necessarily entail changes in system boundaries in order to build resilience. } \\
\text { And in the same fashion, adaptation strategies that include radical change of resource use (in location, } \\
\text { economics or significant land use change for example) may not necessarily be a symptom of a lack of } \\
\text { resilience. }\end{array}$ & $\begin{array}{l}\text { Discussion of how } \\
\text { adaptive actions in } \\
\text { relation to vulnerability } \\
\text { and resilience vary } \\
\text { among actors with } \\
\text { different opportunities. }\end{array}$ & I & $\begin{array}{l}\text { Refer to undervalued } \\
\text { parts of the social- } \\
\text { ecological system which } \\
\text { is clearly normative, but } \\
\text { the adaptation process as } \\
\text { such is described } \\
\text { descriptively, with } \\
\text { adaptations having } \\
\text { different outcomes. Both } \\
\text { normative and analytical } \\
\text { use. }\end{array}$ & SP \\
\hline $\begin{array}{l}\text { Gotts } \\
(2007)\end{array}$ & $\begin{array}{l}\text { p. 6. There is a systematic ambiguity in the term "adaptive," as used in "adaptive cycle." The key } \\
\text { question is: What adapts? In Holland (1992:184-185), } \\
\text { adaptation is a property of organisms or of analogous components of an artificial system. } \\
\text { p. 7. The panarchical perspective has also had little to say about the long-term growth of world population, } \\
\text { energy use and polity size, and the power of technology available for human use. As with the } \\
\text { comparative neglect of conflict and elite dynamics, this is perhaps unsurprising, given its disciplinary roots in } \\
\text { economics, ecosystem science, institutional research, and adaptive complex system theory (Holling } \\
\text { 2003). However, all these factors have enormous implications for the past and future development of } \\
\text { social-ecological systems at all scales. }\end{array}$ & $\begin{array}{l}\text { Several perspectives, } \\
\text { review of adaptive cycle } \\
\text { and adaptations therein. } \\
\text { Notes that the adaptive } \\
\text { cycle critically does not } \\
\text { address power and } \\
\text { political dimensions. }\end{array}$ & B & $\begin{array}{l}\text { No particular norm. } \\
\text { Theoretical discussion on } \\
\text { adaptations only. }\end{array}$ & $\mathrm{D}$ \\
\hline $\begin{array}{l}\text { Janssen et } \\
\text { al. (2007) }\end{array}$ & $\begin{array}{l}\text { p. 309. systems subjected to a particular type and degree of variability may become highly optimized to } \\
\text { tolerate this variability (this characteristic of adaptive systems is referred to as highly optimized tolerance or } \\
\text { HOT). In so doing, how ever, the system may become more brittle and susceptible to changes that may } \\
\text { occur in the type and degree of variability to which it has become highly adapted or to new types of } \\
\text { disturbances. } \\
\text { p. } 311 \text {. We may distinguish two classes of adaptations. First, people have developed institutions over time, } \\
\text { intentionally or not, to spread resource-use intensity over space and/or time in accordance with particular } \\
\text { variability regimes. } \\
\text { p. } 312 \text {. The second class of adaptations is characterized by those directed at managing discrete } \\
\text { disturbances like droughts, cyclones, and price fluctuations. } \\
\text { p. } 312 \text {. For example, from the perspective of higher level authorities, local SES might not be recognized as } \\
\text { being well adapted to the challenges it faces The ambitions of higher level authorities may lead to changes } \\
\text { in local institutions in the expectation of meeting their goals. Lack of understanding of the SES leads to an } \\
\text { inability to meet participants' goals and a reduction of the performance of local and sometimes larger scale } \\
\text { SESs. }\end{array}$ & $\begin{array}{l}\text { Adaptations mentioned } \\
\text { as intentional or not. } \\
\text { Different agendas of } \\
\text { actors referred to. But } \\
\text { also framing of } \\
\text { adaptations as } \\
\text { spontaneous by 'systems' } \\
\text { optimized to tolerate } \\
\text { variability. }\end{array}$ & B & $\begin{array}{l}\text { Vaguely normative e.g. } \\
\text { local SES not recognized } \\
\text { as being well adapted. } \\
\text { Adaptation is about } \\
\text { managing (negative) } \\
\text { disturbance. }\end{array}$ & VN \\
\hline $\begin{array}{l}\text { Duit et al. } \\
\text { (2010) }\end{array}$ & $\begin{array}{l}\text { p. 364. Not only can the natural world be analyzed as a complex dynamic system. It is also possible to view } \\
\text { human-made governance systems consisting of institutions, networks, bureaucracies, and policies as } \\
\text { examples of complex systems inwhich adaptive agents respond to external and internal impulses (cf. Jervis, } \\
\text { 1997; Arthur, 1999; Kooiman, 2003; Teisman et al., 2009). } \\
\text { p 364. From field work across the world, the } 23 \text { case studies reveal a rich variety of circumstances ranging } \\
\text { from environmental emergency migrants, flooding and resettlement suggesting an analytical distinction } \\
\text { between rapid- and slow-onset events. She notes that the development community often } \\
\text { characterizesmigration as a failure of adaptation, rather than as a formof adaptation to environmental and } \\
\text { climate change. } \\
\text { p } 365 \text {. Such thorny normative and conceptual issues notwithstanding, resilience thinking also holds a great } \\
\text { deal of potential for renewing thewider governance research agenda. In particular, it invites us to consider } \\
\text { fundamental issues of change and stability, adaptation and design, hierarchy and self-organization in the } \\
\text { study of multilevel governance systems. Moreover, in addition to "tradi- tional" benchmarks such as }\end{array}$ & $\begin{array}{l}\text { Review CAS as applied } \\
\text { to SES, but also } \\
\text { discusses problem with } \\
\text { spontaneous view and } \\
\text { recognise that } \\
\text { adaptations are always } \\
\text { towards a norm. }\end{array}$ & Both & $\begin{array}{l}\text { Discusses whether } \\
\text { migration is a failure of } \\
\text { adaptation. Vulnerability } \\
\text { resulting from mal- } \\
\text { adaptation is part of } \\
\text { normative evaluation. But } \\
\text { adaptation is also } \\
\text { discussed in terms of } \\
\text { adaptive agents } \\
\text { responding to impulses. }\end{array}$ & SP \\
\hline
\end{tabular}




\begin{tabular}{|l|l|l|l|l|}
\hline & $\begin{array}{l}\text { efficacy, accountability, and equity usedwhen assessing public governance, a resilience perspective on } \\
\text { governance would also consider issues of human-environmental interactions, vulnerability resulting from } \\
\text { mal-adaptations, and innovation capacity as integral parts of evaluating a given governance system (Nelson } \\
\text { et al., 2007). }\end{array}$ & & \\
\hline $\begin{array}{l}\text { Hicks et al. } \\
\text { (2009) }\end{array}$ & No discussion. "adapt*" appear in keywords only & NA & NA & NA \\
\hline
\end{tabular}


Table A2. Categorisation of all 183 papers.

\begin{tabular}{|c|c|c|c|c|}
\hline & Descriptive & Normative & Vaguely normative & Several perspectives \\
\hline Spontaneous & $\begin{array}{l}\text { Berkes, 2010; Bodin, 2009; Bodin, 2005; } \\
\text { Bohensky, 2008; Booher, 2010; } \\
\text { Carpenter, 2008; Cook et al., 2010; } \\
\text { Cumming, 2005; Cundill, 2009; Folke, } \\
\text { 2004; Folke et al., 2002; Gunderson et al., } \\
\text { 2006; Guzy et al., 2008; Lebel et al., } \\
\text { 2006; Levrel, 2008; Liu et al., 2007; } \\
\text { Lubchenco, 2010; Mahon et al., 2008; } \\
\text { Marschke, 2005; Matthews, 2006; } \\
\text { McAllister et al., 2006; Mclntyre, 2009; } \\
\text { Moen, 2010; Nkhata, 2010; Robards, } \\
\text { 2004; Saavedra, 2009; Strickland-Munro } \\
\text { et al., 2010; Tyler et al., 2007; Vetter, } \\
\text { 2009 }\end{array}$ & $\begin{array}{l}\text { Alessa et al., 2008; Anderies et al., 2006; } \\
\text { Baral et al., 2010; Barthel et al., 2005; } \\
\text { Chapin et al., 2010; Dearing, 2008; Elmqvist } \\
\text { et al., 2004; Engle, 2010; Evans, 2008; } \\
\text { Fischer et al., 2009; Gonzalez et al., 2008; } \\
\text { Grafton, 2010; Hagerman et al., 2010; } \\
\text { Hagerman et al., 2010; Holling, 2001; } \\
\text { Krasny, 2010; Langridge et al., 2006; Loring, } \\
\text { 2007; McFadden et al., 2009; O'Rourke, } \\
\text { 2006; Peter et al., 2009; Rammel et al., } \\
\text { 2007; Rescia et al., 2010; Sendzimir et al., } \\
\text { 2008; Walker et al., 2009; Wang, } 2009\end{array}$ & $\begin{array}{l}\text { Allison, 2004; Andrew et al., 2007; Badjeck et } \\
\text { al., 2009; Beratan, 2007; Berkes, 2005; Biggs et } \\
\text { al., 2010; Blackmore, 2008; Borgstrom et al., } \\
\text { 2006; Brown, 2009; Buchmann, 2009; Bunce et } \\
\text { al., 2010; Cowling et al., 2008; Darnhofer et al., } \\
\text { 2010; Dawson et al., 2010; Fernandez-Gimenez } \\
\text { et al., 2008; Hagerman et al., 2010; Higgins et } \\
\text { al., 2010; Jackson et al., 2010; Kalikoski et al.,, } \\
\text { 2010; Krasny, 2009; Lundholm, 2010; Marschke, } \\
\text { 2006; Milestad, 2003; Milestad et al., 2010; } \\
\text { Moser, 2010; Munoz-Erickson et al., 2007; } \\
\text { Plummer, 2010; Schianetz, 2008; Turner et al., } \\
\text { 2007; Warner, 2010 }\end{array}$ & $\begin{array}{l}\text { Schluter et al., 2009; Zhou et } \\
\text { al., } 2010\end{array}$ \\
\hline Intentional & $\begin{array}{l}\text { Artwell et al. 2010; Ballard, 2010; Berkes, } \\
\text { 2006; Brooks et al., 2008; Camargo et al., } \\
\text { 2009; Cundill, 2010; Fazey, 2010; Fennell } \\
\text { et al., 2008; Goldstein, 2008; Gooch, } \\
\text { 2009; Hodge, 2007; Leach, 2008; Lof, } \\
\text { 2010; Miller et al., 2008; O'Brien et al., } \\
\text { 2009; Plummer, 2009; Robinson, 2009; } \\
\text { Serrat-Capdevila et al., 2009; Smith, } \\
\text { 2010; Trainor et al., 2009; Tschakert et } \\
\text { al., 2008; Young et al., 2006 }\end{array}$ & $\begin{array}{l}\text { Abel et al., 2006; Armitage et al., 2009; } \\
\text { Berkes, 2007; Bingeman et al., 2004; } \\
\text { Birkmann, 2010; Ericksen, 2008; Fabricius et } \\
\text { al., 2007; Folke et al., 2005; Galaz, 2005; } \\
\text { Hahn et al., 2006; Milman, 2008; Olsson, } \\
\text { 2001; Olsson et al., 2004a; Powell et al., } \\
\text { 2009; Schultz, 2010; Spies et al., 2010; } \\
\text { Walker et al., 2002; Walker et al., } 2006\end{array}$ & $\begin{array}{l}\text { Armitage et al., 2008; Barnett, 2001; Berkes, } \\
\text { 2002; Boyd, 2010; Chapin et al., 2006; Fazey et } \\
\text { al., 2007; Kofinas et al., 2010; Marshall, 2007; } \\
\text { Nelson et al., 2010; Olsson et al., 2004b; } \\
\text { Sandstrom, } 2010\end{array}$ & $\begin{array}{l}\text { Adger, 2006; Biermann et al., } \\
2010\end{array}$ \\
\hline $\begin{array}{l}\text { Both } \\
\text { spontaneous } \\
\text { and } \\
\text { intentional }\end{array}$ & $\begin{array}{l}\text { Gotts, 2007; Gunderson, 2010; Gupta et } \\
\text { al., 2010; Miller et al., 2010; Schluter, } \\
\text { 2007; van der Brugge, 2007 }\end{array}$ & $\begin{array}{l}\text { Beier et al., 2009; Folke, 2003; Folke et al., } \\
\text { 2007; Olsson et al., 2007; Olsson et al., } \\
\text { 2006; Rescia et al., 2008; Walker et al., } \\
2004\end{array}$ & $\begin{array}{l}\text { Janssen et al., 2007; Nelson et al., 2007; } \\
\text { Nelson, 2009; Renaud et al., 2010; Tidball et al., } \\
\text { 2010; Wardekker et al., 2010; Young, } 2010\end{array}$ & $\begin{array}{l}\text { Duit et al., 2010; Folke, 2006; } \\
\text { Gallopin, 2006; Johnson, } \\
\text { 2010; Marshall, 2010; Osbahr } \\
\text { et al., 2008; Osbahr et al., } \\
\text { 2010; Plummer, 2009; Turner, } \\
2010\end{array}$ \\
\hline
\end{tabular}


Table A3. List of all 183 papers for the structured literature review.

\begin{tabular}{|c|c|c|c|c|c|c|c|}
\hline Author (AU) & $\begin{array}{l}\text { Year } \\
\text { (PY) }\end{array}$ & Title (TI) & Source (SO) & $\begin{array}{l}\text { Volu- } \\
\text { me } \\
\text { (VL) }\end{array}$ & $\begin{array}{l}\text { Issue } \\
\text { (IS) }\end{array}$ & \begin{tabular}{|l} 
Page \\
from \\
(BP)
\end{tabular} & $\begin{array}{l}\text { Page } \\
\text { to } \\
\text { (EP) }\end{array}$ \\
\hline Abel, N; Cumming, DHM; Anderies, JM & 2006 & $\begin{array}{l}\text { Collapse and reorganization in social-ecological systems: Questions, } \\
\text { some ideas, and policy implications }\end{array}$ & ECOLOGY AND SOCIETY & 11 & 1 & & \\
\hline Adger, WN & 2006 & Vulnerability & \begin{tabular}{|l|} 
GLOBAL ENVIRONMENTAL \\
CHANGE-HUMAN AND POLICY \\
DIMENSIONS
\end{tabular} & 16 & 3 & 268 & 281 \\
\hline $\begin{array}{l}\text { Alessa, L; Kliskey, A; Busey, R; Hinzman, L; } \\
\text { White, D }\end{array}$ & 2008 & $\begin{array}{l}\text { Freshwater vulnerabilities and resilience on the Seward Peninsula: } \\
\text { Integrating multiple dimensions of landscape change }\end{array}$ & $\begin{array}{l}\text { GLOBAL ENVIRONMENTAL } \\
\text { CHANGE-HUMAN AND POLICY } \\
\text { DIMENSIONS }\end{array}$ & 18 & 2 & 256 & 270 \\
\hline Allison, HE; Hobbs, RJ & 2004 & $\begin{array}{l}\text { Resilience, adaptive capacity, and the "Lock-in trap" of the Western } \\
\text { Australian agricultural region }\end{array}$ & ECOLOGY AND SOCIETY & 9 & 1 & & \\
\hline Anderies, JM; Ryan, P; Walker, BH & 2006 & $\begin{array}{l}\text { Loss of resilience, crisis, and institutional change: Lessons from an } \\
\text { intensive agricultural system in southeastern Australia }\end{array}$ & ECOSYSTEMS & 9 & 6 & 865 & 878 \\
\hline $\begin{array}{l}\text { Andrew, NL; Bene, C; Hall, SJ; Allison, EH; } \\
\text { Heck, S; Ratner, BD }\end{array}$ & 2007 & $\begin{array}{l}\text { Diagnosis and management of small-scale fisheries in developing } \\
\text { countries }\end{array}$ & FISH AND FISHERIES & 8 & 3 & 227 & 240 \\
\hline Armitage, D; Marschke, M; Plummer, R & 2008 & Adaptive co-management and the paradox of learning & \begin{tabular}{|l|} 
GLOBAL ENVIRONMENTAL \\
CHANGE-HUMAN AND POLICY \\
DIMENSIONS
\end{tabular} & 18 & 1 & 86 & 98 \\
\hline $\begin{array}{l}\text { Armitage, DR; Plummer, R; Berkes, F; Arthur, } \\
\text { RI; Charles, AT; Davidson-Hunt, IJ; Diduck, } \\
\text { AP; Doubleday, NC; Johnson, DS; Marschke, } \\
\text { M; McConney, P; Pinkerton, EW; Wollenberg, } \\
\text { EK }\end{array}$ & 2009 & Adaptive co-management for social-ecological complexity & $\begin{array}{l}\text { FRONTIERS IN ECOLOGY AND } \\
\text { THE ENVIRONMENT }\end{array}$ & 7 & 2 & 95 & 102 \\
\hline Asah, ST & 2008 & $\begin{array}{l}\text { Empirical Social-Ecological System Analysis: From Theoretical } \\
\text { Framework to Latent Variable Structural Equation Model }\end{array}$ & $\begin{array}{l}\text { ENVIRONMENTAL } \\
\text { MANAGEMENT }\end{array}$ & 42 & 6 & 1077 & 1090 \\
\hline Atwell, RC; Schulte, LA; Westphal, LM & 2009 & $\begin{array}{l}\text { Linking Resilience Theory and Diffusion of Innovations Theory to } \\
\text { Understand the Potential for Perennials in the US Corn Belt }\end{array}$ & ECOLOGY AND SOCIETY & 14 & 1 & & \\
\hline Atwell, RC; Schulte, LA; Westphal, LM & 2010 & $\begin{array}{l}\text { How to build multifunctional agricultural landscapes in the US Corn Belt: } \\
\text { Add perennials and partnerships }\end{array}$ & LAND USE POLICY & 27 & 4 & 1082 & 1090 \\
\hline Badjeck, MC; Mendo, J; Wolff, M; Lange, H & 2009 & $\begin{array}{l}\text { Climate variability and the Peruvian scallop fishery: the role of formal } \\
\text { institutions in resilience building }\end{array}$ & CLIMATIC CHANGE & 94 & 40545 & 211 & 232 \\
\hline Ballard, HL; Belsky, JM & 2010 & $\begin{array}{l}\text { Participatory action research and environmental learning: implications } \\
\text { for resilient forests and communities }\end{array}$ & $\begin{array}{l}\text { ENVIRONMENTAL } \\
\text { EDUCATION RESEARCH }\end{array}$ & 16 & 40669 & 611 & 627 \\
\hline Baral, N; Stern, MJ; Heinen, JT & 2010 & $\begin{array}{l}\text { Growth, Collapse, and Reorganization of the Annapurna Conservation } \\
\text { Area, Nepal: an Analysis of Institutional Resilience }\end{array}$ & ECOLOGY AND SOCIETY & 15 & 3 & & \\
\hline
\end{tabular}




\begin{tabular}{|c|c|c|c|c|c|c|c|}
\hline Barnett, J & 2001 & $\begin{array}{l}\text { Adapting to climate change in Pacific Island Countries: The problem of } \\
\text { uncertainty }\end{array}$ & WORLD DEVELOPMENT & 29 & 6 & 977 & 993 \\
\hline Barthel, S; Colding, J; Elmqvist, T; Folke, C & 2005 & $\begin{array}{l}\text { History and local management of a biodiversity-rich, urban cultural } \\
\text { landscape }\end{array}$ & ECOLOGY AND SOCIETY & 10 & 2 & & \\
\hline Beier, CM; Lovecraft, AL; Chapin, FS & 2009 & $\begin{array}{l}\text { Growth and Collapse of a Resource System: an Adaptive Cycle of } \\
\text { Change in Public Lands Governance and Forest Management in Alaska }\end{array}$ & ECOLOGY AND SOCIETY & 14 & 2 & & \\
\hline Beier, CM; Patterson, TM; Chapin, FS & 2008 & $\begin{array}{l}\text { Ecosystem services and emergent vulnerability in managed } \\
\text { ecosystems: A geospatial decision-support tool }\end{array}$ & ECOSYSTEMS & 11 & 6 & 923 & 938 \\
\hline Beratan, KK & 2007 & $\begin{array}{l}\text { A cognition-based view of decision processes in complex social- } \\
\text { ecological systems }\end{array}$ & ECOLOGY AND SOCIETY & 12 & 1 & & \\
\hline Berkes, $\mathrm{F}$ & 2007 & $\begin{array}{l}\text { Understanding uncertainty and reducing vulnerability: lessons from } \\
\text { resilience thinking }\end{array}$ & NATURAL HAZARDS & 41 & 2 & 283 & 295 \\
\hline Berkes, $\mathrm{F}$ & 2010 & Devolution of environment and resources governance: trends and future & $\begin{array}{l}\text { ENVIRONMENTAL } \\
\text { CONSERVATION }\end{array}$ & 37 & 4 & 489 & 500 \\
\hline Berkes, F; Jolly, D & 2002 & $\begin{array}{l}\text { Adapting to climate change: Social-ecological resilience in a Canadian } \\
\text { Western Arctic community }\end{array}$ & CONSERVATION ECOLOGY & 5 & 2 & & \\
\hline Berkes, F; Seixas, CS & 2005 & $\begin{array}{l}\text { Building resilience in lagoon social-ecological systems: A local-level } \\
\text { perspective }\end{array}$ & ECOSYSTEMS & 8 & 8 & 967 & 974 \\
\hline Berkes, F; Turner, NJ & 2006 & $\begin{array}{l}\text { Knowledge, learning and the evolution of conservation practice for } \\
\text { social-ecological system resilience }\end{array}$ & HUMAN ECOLOGY & 34 & 4 & 479 & 494 \\
\hline $\begin{array}{l}\text { Biermann, F; Betsill, MM; Vieira, SC; Gupta, J; } \\
\text { Kanie, N; Lebel, L; Liverman, D; Schroeder, H; } \\
\text { Siebenhuner, B; Yanda, PZ; Zondervan, R }\end{array}$ & 2010 & $\begin{array}{l}\text { Navigating the anthropocene: the Earth System Governance Project } \\
\text { strategy paper }\end{array}$ & \begin{tabular}{|l|} 
CURRENT OPINION IN \\
ENVIRONMENTAL \\
SUSTAINABILITY \\
\end{tabular} & 2 & 3 & 202 & 208 \\
\hline Biggs, R; Westley, FR; Carpenter, SR & 2010 & $\begin{array}{l}\text { Navigating the Back Loop: Fostering Social Innovation and } \\
\text { Transformation in Ecosystem Management }\end{array}$ & ECOLOGY AND SOCIETY & 15 & 2 & & \\
\hline Bingeman, K; Berkes, F; Gardner, JS & 2004 & $\begin{array}{l}\text { Institutional responses to development pressures: Resilience of social- } \\
\text { ecological systems in Himachal Pradesh, India }\end{array}$ & $\begin{array}{l}\text { INTERNATIONAL JOURNAL OF } \\
\text { SUSTAINABLE } \\
\text { DEVELOPMENT AND WORLD } \\
\text { ECOLOGY }\end{array}$ & 11 & 1 & 99 & 115 \\
\hline Birkmann, J; von Teichman, $\mathrm{K}$ & 2010 & $\begin{array}{l}\text { Integrating disaster risk reduction and climate change adaptation: key } \\
\text { challenges-scales, knowledge, and norms }\end{array}$ & SUSTAINABILITY SCIENCE & 5 & 2 & 171 & 184 \\
\hline Blackmore, JM; Plant, RAJ & 2008 & $\begin{array}{l}\text { Risk and resilience to enhance sustainability with application to urban } \\
\text { water systems }\end{array}$ & \begin{tabular}{|l|} 
JOURNAL OF WATER \\
RESOURCES PLANNING AND \\
MANAGEMENT-ASCE
\end{tabular} & 134 & 3 & 224 & 233 \\
\hline Bodin, O; Crona, BI & 2009 & $\begin{array}{l}\text { The role of social networks in natural resource governance: What } \\
\text { relational patterns make a difference? }\end{array}$ & \begin{tabular}{|l|} 
GLOBAL ENVIRONMENTAL \\
CHANGE-HUMAN AND POLICY \\
DIMENSIONS
\end{tabular} & 19 & 3 & 366 & 374 \\
\hline Bodin, O; Norberg, J & 2005 & $\begin{array}{l}\text { Information network topologies for enhanced local adaptive } \\
\text { management }\end{array}$ & $\begin{array}{l}\text { ENVIRONMENTAL } \\
\text { MANAGEMENT }\end{array}$ & 35 & 2 & 175 & 193 \\
\hline
\end{tabular}




\begin{tabular}{|c|c|c|c|c|c|c|c|}
\hline Bohensky, EL & 2008 & $\begin{array}{l}\text { Discovering Resilient Pathways for South African Water Management: } \\
\text { Two Frameworks for a Vision }\end{array}$ & ECOLOGY AND SOCIETY & 13 & 1 & & \\
\hline Booher, DE; Innes, JE & 2010 & $\begin{array}{l}\text { Governance for Resilience: CALFED as a Complex Adaptive Network } \\
\text { for Resource Management }\end{array}$ & ECOLOGY AND SOCIETY & 15 & 3 & & \\
\hline $\begin{array}{l}\text { Borgstrom, ST; Elmqvist, T; Angelstam, P; } \\
\text { Alfsen-Norodom, C }\end{array}$ & 2006 & Scale mismatches in management of urban landscapes & ECOLOGY AND SOCIETY & 11 & 2 & & \\
\hline Boyd, E; Osbahr, H & 2010 & $\begin{array}{l}\text { Responses to climate change: exploring organisational learning across } \\
\text { internationally networked organisations for development }\end{array}$ & $\begin{array}{l}\text { ENVIRONMENTAL } \\
\text { EDUCATION RESEARCH }\end{array}$ & 16 & 40669 & 629 & 643 \\
\hline Brooks, S; Reynolds, J; Allison, E & 2008 & $\begin{array}{l}\text { Sustained by Snakes? Seasonal Livelihood Strategies and Resource } \\
\text { Conservation by Tonle Sap Fishers in Cambodia }\end{array}$ & HUMAN ECOLOGY & 36 & 6 & 835 & 851 \\
\hline Brown, HCP & 2009 & $\begin{array}{l}\text { Climate change and Ontario forests: Prospects for building institutional } \\
\text { adaptive capacity }\end{array}$ & $\begin{array}{l}\text { MITIGATION AND } \\
\text { ADAPTATION STRATEGIES } \\
\text { FOR GLOBAL CHANGE }\end{array}$ & 14 & 6 & 513 & 536 \\
\hline Buchmann, C & 2009 & Cuban Home Gardens and Their Role in Social-Ecological Resilience & HUMAN ECOLOGY & 37 & 6 & 705 & 721 \\
\hline Bunce, M; Brown, K; Rosendo, S & 2010 & $\begin{array}{l}\text { Policy misfits, climate change and cross-scale vulnerability in coastal } \\
\text { Africa: how development projects undermine resilience }\end{array}$ & $\begin{array}{l}\text { ENVIRONMENTAL SCIENCE \& } \\
\text { POLICY }\end{array}$ & 13 & 6 & 485 & 497 \\
\hline $\begin{array}{l}\text { Camargo, C; Maldonado, JH; Alvarado, E; } \\
\text { Moreno-Sanchez, R; Mendoza, S; Manrique, N; } \\
\text { Mogollon, A; Osorio, JD; Grajales, A; Sanchez, } \\
\text { JA }\end{array}$ & 2009 & $\begin{array}{l}\text { Community involvement in management for maintaining coral reef } \\
\text { resilience and biodiversity in southern Caribbean marine protected } \\
\text { areas }\end{array}$ & $\begin{array}{l}\text { BIODIVERSITY AND } \\
\text { CONSERVATION }\end{array}$ & 18 & 4 & 935 & 956 \\
\hline Carpenter, SR; Brock, WA & 2008 & Adaptive Capacity and Traps & ECOLOGY AND SOCIETY & 13 & 2 & & \\
\hline $\begin{array}{l}\text { Chapin, FS; Carpenter, SR; Kofinas, GP; } \\
\text { Folke, C; Abel, N; Clark, WC; Olsson, P; Smith, } \\
\text { DMS; Walker, B; Young, OR; Berkes, F; Biggs, } \\
\text { R; Grove, JM; Naylor, RL; Pinkerton, E; } \\
\text { Steffen, W; Swanson, FJ }\end{array}$ & 2010 & $\begin{array}{l}\text { Ecosystem stewardship: sustainability strategies for a rapidly changing } \\
\text { planet }\end{array}$ & $\begin{array}{l}\text { TRENDS IN ECOLOGY \& } \\
\text { EVOLUTION }\end{array}$ & 25 & 4 & 241 & 249 \\
\hline $\begin{array}{l}\text { Chapin, FS; Lovecraft, AL; Zavaleta, ES; } \\
\text { Nelson, J; Robards, MD; Kofinas, GP; Trainor, } \\
\text { SF; Peterson, GD; Huntington, HP; Naylor, RL }\end{array}$ & 2006 & $\begin{array}{l}\text { Policy strategies to address sustainability of Alaskan boreal forests in } \\
\text { response to a directionally changing climate }\end{array}$ & $\begin{array}{l}\text { PROCEEDINGS OF THE } \\
\text { NATIONAL ACADEMY OF } \\
\text { SCIENCES OF THE UNITED } \\
\text { STATES OF AMERICA } \\
\end{array}$ & 103 & 45 & 16637 & 16643 \\
\hline Cook, DC; Liu, SG; Murphy, B; Lonsdale, WM & 2010 & Adaptive Approaches to Biosecurity Governance & RISK ANALYSIS & 30 & 9 & 1303 & 1314 \\
\hline $\begin{array}{l}\text { Cowling, RM; Egoh, B; Knight, AT; O'Farrell, } \\
\text { PJ; Reyers, B; Rouget'll, M; Roux, DJ; Welz, A; } \\
\text { Wilhelm-Rechman, A }\end{array}$ & 2008 & $\begin{array}{l}\text { An operational model for mainstreaming ecosystem services for } \\
\text { implementation }\end{array}$ & $\begin{array}{l}\text { PROCEEDINGS OF THE } \\
\text { NATIONAL ACADEMY OF } \\
\text { SCIENCES OF THE UNITED } \\
\text { STATES OF AMERICA } \\
\end{array}$ & 105 & 28 & 9483 & 9488 \\
\hline Craig, RK & 2010 & $\begin{array}{l}\text { STATIONARITY IS DEAD - LONG LIVE TRANSFORMATION: FIVE } \\
\text { PRINCIPLES FOR CLIMATE CHANGE ADAPTATION LAW }\end{array}$ & $\begin{array}{l}\text { HARVARD ENVIRONMENTAL } \\
\text { LAW REVIEW }\end{array}$ & 34 & 1 & 9 & 73 \\
\hline Cumming, GS; Collier, J & 2005 & Change and identity in complex systems & ECOLOGY AND SOCIETY & 10 & 1 & & \\
\hline Cundill, G; Fabricius, C & 2009 & $\begin{array}{l}\text { Monitoring in adaptive co-management: Toward a learning based } \\
\text { approach }\end{array}$ & \begin{tabular}{|l} 
JOURNAL OF \\
ENVIRONMENTAL \\
MANAGEMENT
\end{tabular} & 90 & 11 & 3205 & 3211 \\
\hline
\end{tabular}




\begin{tabular}{|c|c|c|c|c|c|c|c|}
\hline Cundill, G; Fabricius, C & 2010 & $\begin{array}{l}\text { Monitoring the Governance Dimension of Natural Resource Co- } \\
\text { management }\end{array}$ & ECOLOGY AND SOCIETY & 15 & 1 & & \\
\hline Darnhofer, I; Fairweather, J; Moller, H & 2010 & Assessing a farm's sustainability: insights from resilience thinking & $\begin{array}{l}\text { INTERNATIONAL JOURNAL OF } \\
\text { AGRICULTURAL } \\
\text { SUSTAINABILITY }\end{array}$ & 8 & 3 & 186 & 198 \\
\hline $\begin{array}{l}\text { Dawson, TP; Rounsevell, MDA; Kluvankova- } \\
\text { Oravska, T; Chobotova, V; Stirling, A }\end{array}$ & 2010 & $\begin{array}{l}\text { Dynamic properties of complex adaptive ecosystems: implications for } \\
\text { the sustainability of service provision }\end{array}$ & $\begin{array}{l}\text { BIODIVERSITY AND } \\
\text { CONSERVATION }\end{array}$ & 19 & 10 & 2843 & 2853 \\
\hline Dearing, JA & 2008 & $\begin{array}{l}\text { Landscape change and resilience theory: a palaeoenvironmental } \\
\text { assessment from Yunnan, SW China }\end{array}$ & HOLOCENE & 18 & 1 & 117 & 127 \\
\hline Dikau, $\mathrm{R}$ & 2006 & Complex systems in geomorphology & $\begin{array}{l}\text { MITTEILUNGEN DER } \\
\text { OSTERREICHISCHEN } \\
\text { GEOGRAPHISCHEN } \\
\text { GESELLSCHAFT }\end{array}$ & 148 & & 125 & 150 \\
\hline Duit, A; Galaz, V; Eckerberg, K; Ebbesson, J & 2010 & Governance, complexity, and resilience Introduction & $\begin{array}{l}\text { GLOBAL ENVIRONMENTAL } \\
\text { CHANGE-HUMAN AND POLICY } \\
\text { DIMENSIONS } \\
\end{array}$ & 20 & 3 & 363 & 368 \\
\hline $\begin{array}{l}\text { Elmqvist, T; Colding, J; Barthel, S; Borgstrom, } \\
\text { S; Duit, A; Lundberg, J; Andersson, E; Ahrne, } \\
\text { K; Ernstson, H; Folke, C; Bengtsson, J } \\
\end{array}$ & 2004 & $\begin{array}{l}\text { The dynamics of social-ecological systems in urban landscapes - } \\
\text { Stockholm and the National Urban Park, Sweden }\end{array}$ & $\begin{array}{l}\text { URBAN BIOSPHERE AND } \\
\text { SOCIETY: PARTNERSHIP OF } \\
\text { CITIES }\end{array}$ & 1023 & & 308 & 322 \\
\hline Engle, NL; Lemos, MC & 2010 & $\begin{array}{l}\text { Unpacking governance: Building adaptive capacity to climate change of } \\
\text { river basins in Brazil }\end{array}$ & $\begin{array}{l}\text { GLOBAL ENVIRONMENTAL } \\
\text { CHANGE-HUMAN AND POLICY } \\
\text { DIMENSIONS }\end{array}$ & 20 & 1 & 4 & 13 \\
\hline Ericksen, PJ & 2008 & $\begin{array}{l}\text { What Is the Vulnerability of a Food System to Global Environmental } \\
\text { Change? }\end{array}$ & ECOLOGY AND SOCIETY & 13 & 2 & & \\
\hline Evans, GR & 2008 & $\begin{array}{l}\text { Transformation from "Carbon Valley" to a "Post-Carbon Society" in a } \\
\text { Climate Change Hot Spot: the Coalfields of the Hunter Valley, New } \\
\text { South Wales, Australia }\end{array}$ & ECOLOGY AND SOCIETY & 13 & 1 & & \\
\hline Fabricius, C; Folke, C; Cundill, G; Schultz, L & 2007 & $\begin{array}{l}\text { Powerless spectators, coping actors, and adaptive co-managers: a } \\
\text { synthesis of the role of communities in ecosystem management }\end{array}$ & ECOLOGY AND SOCIETY & 12 & 1 & & \\
\hline Fazey, I & 2010 & Resilience and Higher Order Thinking & ECOLOGY AND SOCIETY & 15 & 3 & & \\
\hline $\begin{array}{l}\text { Fazey, I; Fazey, JA; Fischer, J; Sherren, K; } \\
\text { Warren, J; Noss, RF; Dovers, SR }\end{array}$ & 2007 & $\begin{array}{l}\text { Adaptive capacity and learning to learn as leverage for social-ecological } \\
\text { resilience }\end{array}$ & $\begin{array}{l}\text { FRONTIERS IN ECOLOGY AND } \\
\text { THE ENVIRONMENT }\end{array}$ & 5 & 7 & 375 & 380 \\
\hline Fennell, D; Plummer, R; Marschke, M & 2008 & Is adaptive co-management ethical? & \begin{tabular}{|l} 
JOURNAL OF \\
ENVIRONMENTAL \\
MANAGEMENT \\
\end{tabular} & 88 & 1 & 62 & 75 \\
\hline $\begin{array}{l}\text { Fernandez-Gimenez, ME; Ballard, HL; } \\
\text { Sturtevant, VE }\end{array}$ & 2008 & $\begin{array}{l}\text { Adaptive Management and Social Learning in Collaborative and } \\
\text { Community-Based Monitoring: a Study of Five Community-Based } \\
\text { Forestry Organizations in the western USA }\end{array}$ & ECOLOGY AND SOCIETY & 13 & 2 & & \\
\hline $\begin{array}{l}\text { Fischer, J; Peterson, GD; Gardner, TA; } \\
\text { Gordon, LJ; Fazey, I; Elmqvist, T; Felton, A; } \\
\text { Folke, C; Dovers, S }\end{array}$ & 2009 & Integrating resilience thinking and optimisation for conservation & $\begin{array}{l}\text { TRENDS IN ECOLOGY \& } \\
\text { EVOLUTION }\end{array}$ & 24 & 10 & 549 & 554 \\
\hline Folke, C & 2004 & Traditional knowledge in social-ecological systems & ECOLOGY AND SOCIETY & 9 & 3 & & \\
\hline
\end{tabular}




\begin{tabular}{|c|c|c|c|c|c|c|c|}
\hline Folke, C & 2003 & Freshwater for resilience: a shift in thinking & $\begin{array}{l}\text { PHILOSOPHICAL } \\
\text { TRANSACTIONS OF THE } \\
\text { ROYAL SOCIETY OF LONDON } \\
\text { SERIES B-BIOLOGICAL } \\
\text { SCIENCES }\end{array}$ & 358 & 1440 & 2027 & 2036 \\
\hline Folke, C & 2006 & $\begin{array}{l}\text { Resilience: The emergence of a perspective for social-ecological } \\
\text { systems analyses }\end{array}$ & $\begin{array}{l}\text { GLOBAL ENVIRONMENTAL } \\
\text { CHANGE-HUMAN AND POLICY } \\
\text { DIMENSIONS }\end{array}$ & 16 & 3 & 253 & 267 \\
\hline $\begin{array}{l}\text { Folke, C; Carpenter, S; Elmqvist, T; } \\
\text { Gunderson, L; Holling, CS; Walker, B }\end{array}$ & 2002 & $\begin{array}{l}\text { Resilience and sustainable development: Building adaptive capacity in a } \\
\text { world of transformations }\end{array}$ & AMBIO & 31 & 5 & 437 & 440 \\
\hline Folke, C; Hahn, T; Olsson, P; Norberg, J & 2005 & Adaptive governance of social-ecological systems & $\begin{array}{l}\text { ANNUAL REVIEW OF } \\
\text { ENVIRONMENT AND } \\
\text { RESOURCES }\end{array}$ & 30 & & 441 & 473 \\
\hline $\begin{array}{l}\text { Folke, C; Pritchard, L; Berkes, F; Colding, J; } \\
\text { Svedin, U }\end{array}$ & 2007 & The problem of fit between ecosystems and institutions: Ten years later & ECOLOGY AND SOCIETY & 12 & 1 & & \\
\hline Galaz, V & 2005 & $\begin{array}{l}\text { Social-ecological resilience and social conflict: Institutions and strategic } \\
\text { adaptation in Swedish water management }\end{array}$ & AMBIO & 34 & 7 & 567 & 572 \\
\hline Gallopin, GC & 2006 & Linkages between vulnerability, resilience, and adaptive capacity & \begin{tabular}{|l|} 
GLOBAL ENVIRONMENTAL \\
CHANGE-HUMAN AND POLICY \\
DIMENSIONS
\end{tabular} & 16 & 3 & 293 & 303 \\
\hline Goldstein, BE & 2008 & $\begin{array}{l}\text { Skunkworks in the embers of the Cedar fire: Enhancing resilience in the } \\
\text { aftermath of disaster }\end{array}$ & HUMAN ECOLOGY & 36 & 1 & 15 & 28 \\
\hline $\begin{array}{l}\text { Gonzalez, JA; Montes, C; Rodriguez, J; Tapia, } \\
\text { W }\end{array}$ & 2008 & $\begin{array}{l}\text { Rethinking the Galapagos Islands as a Complex Social-Ecological } \\
\text { System: Implications for Conservation and Management }\end{array}$ & ECOLOGY AND SOCIETY & 13 & 2 & & \\
\hline Gooch, M; Warburton, J & 2009 & $\begin{array}{l}\text { Building and Managing Resilience in Community-Based NRM Groups: } \\
\text { An Australian Case Study }\end{array}$ & $\begin{array}{l}\text { SOCIETY \& NATURAL } \\
\text { RESOURCES }\end{array}$ & 22 & 2 & 158 & 171 \\
\hline Gotts, NM & 2007 & Resilience, panarchy, and world-systems analysis & ECOLOGY AND SOCIETY & 12 & 1 & & \\
\hline Grafton, $R Q$ & 2010 & Adaptation to climate change in marine capture fisheries & MARINE POLICY & 34 & 3 & 606 & 615 \\
\hline Gunderson, L & 2010 & $\begin{array}{l}\text { Ecological and Human Community Resilience in Response to Natural } \\
\text { Disasters }\end{array}$ & ECOLOGY AND SOCIETY & 15 & 2 & & \\
\hline $\begin{array}{l}\text { Gunderson, LH; Carpenter, SR; Folke, C; } \\
\text { Olsson, P; Peterson, G }\end{array}$ & 2006 & $\begin{array}{l}\text { Water RATs (resilience, adaptability, and transformability) in lake and } \\
\text { wetland social-ecological systems }\end{array}$ & ECOLOGY AND SOCIETY & 11 & 1 & & \\
\hline $\begin{array}{l}\text { Gupta, J; Termeer, C; Klostermann, J; } \\
\text { Meijerink, S; van den Brink, M; Jong, P; } \\
\text { Nooteboom, S; Bergsma, E }\end{array}$ & 2010 & $\begin{array}{l}\text { The Adaptive Capacity Wheel: a method to assess the inherent } \\
\text { characteristics of institutions to enable the adaptive capacity of society }\end{array}$ & $\begin{array}{l}\text { ENVIRONMENTAL SCIENCE \& } \\
\text { POLICY }\end{array}$ & 13 & 6 & 459 & 471 \\
\hline $\begin{array}{l}\text { Guzy, MR; Smith, CL; Bolte, JP; Hulse, DW; } \\
\text { Gregory, SV }\end{array}$ & 2008 & $\begin{array}{l}\text { Policy Research Using Agent-Based Modeling to Assess Future Impacts } \\
\text { of Urban Expansion into Farmlands and Forests }\end{array}$ & ECOLOGY AND SOCIETY & 13 & 1 & & \\
\hline $\begin{array}{l}\text { Hagerman, S; Dowlatabadi, H; Chan, KMA; } \\
\text { Satterfield, T }\end{array}$ & 2010 & $\begin{array}{l}\text { Integrative propositions for adapting conservation policy to the impacts } \\
\text { of climate change }\end{array}$ & \begin{tabular}{|l|} 
GLOBAL ENVIRONMENTAL \\
CHANGE-HUMAN AND POLICY \\
DIMENSIONS
\end{tabular} & 20 & 2 & 351 & 362 \\
\hline
\end{tabular}




\begin{tabular}{|c|c|c|c|c|c|c|c|}
\hline $\begin{array}{l}\text { Hagerman, S; Dowlatabadi, H; Satterfield, T; } \\
\text { McDaniels, T }\end{array}$ & 2010 & Expert views on biodiversity conservation in an era of climate change & $\begin{array}{l}\text { GLOBAL ENVIRONMENTAL } \\
\text { CHANGE-HUMAN AND POLICY } \\
\text { DIMENSIONS }\end{array}$ & 20 & 1 & 192 & 207 \\
\hline Hagerman, SM; Dowlatabadi, H; Satterfield, T & 2010 & $\begin{array}{l}\text { Observations on Drivers and Dynamics of Environmental Policy } \\
\text { Change: Insights from } 150 \text { Years of Forest Management in British } \\
\text { Columbia }\end{array}$ & ECOLOGY AND SOCIETY & 15 & 1 & & \\
\hline Hahn, T; Olsson, P; Folke, C; Johansson, K & 2006 & $\begin{array}{l}\text { Trust-building, knowledge generation and organizational innovations: } \\
\text { The role of a bridging organization for adaptive comanagement of a } \\
\text { wetland landscape around Kristianstad, Sweden }\end{array}$ & HUMAN ECOLOGY & 34 & 4 & 573 & 592 \\
\hline $\begin{array}{l}\text { Hicks, CC; McClanahan, TR; Cinner, JE; Hills, } \\
\text { JM }\end{array}$ & 2009 & $\begin{array}{l}\text { Trade-Offs in Values Assigned to Ecological Goods and Services } \\
\text { Associated with Different Coral Reef Management Strategies }\end{array}$ & ECOLOGY AND SOCIETY & 14 & 1 & & \\
\hline $\begin{array}{l}\text { Higgins, AJ; Miller, CJ; Archer, AA; Ton, T; } \\
\text { Fletcher, CS; McAllister, RRJ }\end{array}$ & 2010 & Challenges of operations research practice in agricultural value chains & $\begin{array}{l}\text { JOURNAL OF THE } \\
\text { OPERATIONAL RESEARCH } \\
\text { SOCIETY }\end{array}$ & 61 & 6 & 964 & 973 \\
\hline Hodge, I & 2007 & The governance of rural land in a liberalised world & \begin{tabular}{|l|} 
JOURNAL OF AGRICULTURAL \\
ECONOMICS
\end{tabular} & 58 & 3 & 409 & 432 \\
\hline Holling, CS & 2001 & $\begin{array}{l}\text { Understanding the complexity of economic, ecological, and social } \\
\text { systems }\end{array}$ & ECOSYSTEMS & 4 & 5 & 390 & 405 \\
\hline $\begin{array}{l}\text { Jackson, L; van Noordwijk, M; Bengtsson, J; } \\
\text { Foster, W; Lipper, L; Pulleman, M; Said, M; } \\
\text { Snaddon, J; Vodouhe, R } \\
\end{array}$ & 2010 & $\begin{array}{l}\text { Biodiversity and agricultural sustainagility: from assessment to adaptive } \\
\text { management }\end{array}$ & $\begin{array}{l}\text { CURRENT OPINION IN } \\
\text { ENVIRONMENTAL } \\
\text { SUSTAINABILITY } \\
\end{array}$ & 2 & 40545 & 80 & 87 \\
\hline Janssen, MA; Anderies, JM; Ostrom, E & 2007 & $\begin{array}{l}\text { Robustness of social-ecological systems to spatial and temporal } \\
\text { variability }\end{array}$ & $\begin{array}{l}\text { SOCIETY \& NATURAL } \\
\text { RESOURCES }\end{array}$ & 20 & 4 & 307 & 322 \\
\hline Johnson, DS & 2010 & $\begin{array}{l}\text { Institutional adaptation as a governability problem in fisheries: patron- } \\
\text { client relations in the Junagadh fishery, India }\end{array}$ & FISH AND FISHERIES & 11 & 3 & 264 & 277 \\
\hline Kalikoski, DC; Neto, PQ; Almudi, T & 2010 & $\begin{array}{l}\text { Building adaptive capacity to climate variability: The case of artisanal } \\
\text { fisheries in the estuary of the Patos Lagoon, Brazil }\end{array}$ & MARINE POLICY & 34 & 4 & 742 & 751 \\
\hline $\begin{array}{l}\text { Kofinas, GP; Chapin, FS; BurnSilver, S; } \\
\text { Schmidt, JI; Fresco, NL; Kielland, K; Martin, S; } \\
\text { Springsteen, A; Rupp, TS }\end{array}$ & 2010 & $\begin{array}{l}\text { Resilience of Athabascan subsistence systems to interior Alaska's } \\
\text { changing climate }\end{array}$ & $\begin{array}{l}\text { CANADIAN JOURNAL OF } \\
\text { FOREST RESEARCH-REVUE } \\
\text { CANADIENNE DE } \\
\text { RECHERCHE FORESTIERE }\end{array}$ & 40 & 7 & 1347 & 1359 \\
\hline Krasny, ME; Lundholm, C; Plummer, R & 2010 & $\begin{array}{l}\text { Environmental education, resilience, and learning: reflection and moving } \\
\text { forward }\end{array}$ & $\begin{array}{l}\text { ENVIRONMENTAL } \\
\text { EDUCATION RESEARCH }\end{array}$ & 16 & 40669 & 665 & 672 \\
\hline Krasny, ME; Roth, WM & 2010 & $\begin{array}{l}\text { Environmental education for social-ecological system resilience: a } \\
\text { perspective from activity theory }\end{array}$ & $\begin{array}{l}\text { ENVIRONMENTAL } \\
\text { EDUCATION RESEARCH }\end{array}$ & 16 & 40669 & 545 & 558 \\
\hline Krasny, ME; Tidball, KG & 2009 & $\begin{array}{l}\text { Applying a resilience systems framework to urban environmental } \\
\text { education }\end{array}$ & $\begin{array}{l}\text { ENVIRONMENTAL } \\
\text { EDUCATION RESEARCH }\end{array}$ & 15 & 4 & 465 & 482 \\
\hline Krasny, ME; Tidball, KG; Sriskandarajah, N & 2009 & $\begin{array}{l}\text { Education and Resilience: Social and Situated Learning among } \\
\text { University and Secondary Students }\end{array}$ & ECOLOGY AND SOCIETY & 14 & 2 & & \\
\hline
\end{tabular}




\begin{tabular}{|c|c|c|c|c|c|c|c|}
\hline Langridge, R; Christian-Smith, J; Lohse, KA & 2006 & $\begin{array}{l}\text { Access and resilience: Analyzing the construction of social resilience to } \\
\text { the threat of water scarcity }\end{array}$ & ECOLOGY AND SOCIETY & 11 & 2 & & \\
\hline Leach, M & 2008 & $\begin{array}{l}\text { Pathways to Sustainability in the forest? Misunderstood dynamics and } \\
\text { the negotiation of knowledge, power, and policy }\end{array}$ & $\begin{array}{l}\text { ENVIRONMENT AND } \\
\text { PLANNING A }\end{array}$ & 40 & 8 & 1783 & 1795 \\
\hline Leach, M; Scoones, I; Stirling, A & 2010 & $\begin{array}{l}\text { Governing epidemics in an age of complexity: Narratives, politics and } \\
\text { pathways to sustainability }\end{array}$ & $\begin{array}{l}\text { GLOBAL ENVIRONMENTAL } \\
\text { CHANGE-HUMAN AND POLICY } \\
\text { DIMENSIONS }\end{array}$ & 20 & 3 & 369 & 377 \\
\hline $\begin{array}{l}\text { Lebel, L; Anderies, JM; Campbell, B; Folke, C; } \\
\text { Hatfield-Dodds, S; Hughes, TP; Wilson, J }\end{array}$ & 2006 & $\begin{array}{l}\text { Governance and the capacity to manage resilience in regional social- } \\
\text { ecological systems }\end{array}$ & ECOLOGY AND SOCIETY & 11 & 1 & & \\
\hline Levrel, H; Bouamrane, M & 2008 & $\begin{array}{l}\text { Instrumental Learning and Sustainability Indicators: Outputs from Co- } \\
\text { Construction Experiments in West African Biosphere Reserves }\end{array}$ & ECOLOGY AND SOCIETY & 13 & 1 & & \\
\hline $\begin{array}{l}\text { Liu, JG; Dietz, T; Carpenter, SR; Folke, C; } \\
\text { Alberti, M; Redman, CL; Schneider, SH; } \\
\text { Ostrom, E; Pell, AN; Lubchenco, J; Taylor, } \\
\text { WW; Ouyang, ZY; Deadman, P; Kratz, T; } \\
\text { Provencher, W }\end{array}$ & 2007 & Coupled human and natural systems & AMBIO & 36 & 8 & 639 & 649 \\
\hline Lof, A & 2010 & Exploring adaptability through learning layers and learning loops & \begin{tabular}{|l|} 
ENVIRONMENTAL \\
EDUCATION RESEARCH
\end{tabular} & 16 & 40669 & 529 & 543 \\
\hline Loring, PA & 2007 & $\begin{array}{l}\text { The most resilient show on earth: The circus as a model for viewing } \\
\text { identity, change, and chaos }\end{array}$ & ECOLOGY AND SOCIETY & 12 & 1 & & \\
\hline Lubchenco, J; Petes, LE & 2010 & The Interconnected Biosphere: Science at the Ocean's Tipping Points & OCEANOGRAPHY & 23 & 2 & 115 & 129 \\
\hline Lundholm, C; Plummer, R & 2010 & Resilience and learning: a conspectus for environmental education & $\begin{array}{l}\text { ENVIRONMENTAL } \\
\text { EDUCATION RESEARCH }\end{array}$ & 16 & 40669 & 475 & 491 \\
\hline MacMynowski, DP & 2007 & $\begin{array}{l}\text { Across space and time: Social responses to large-scale biophysical } \\
\text { systems }\end{array}$ & $\begin{array}{l}\text { ENVIRONMENTAL } \\
\text { MANAGEMENT }\end{array}$ & 39 & 6 & 831 & 842 \\
\hline Mahon, R; McConney, P; Roy, RN & 2008 & Governing fisheries as complex adaptive systems & MARINE POLICY & 32 & 1 & 104 & 112 \\
\hline Marschke, M; Berkes, F & 2005 & $\begin{array}{l}\text { Local level sustainability planning for livelihoods: A Cambodian } \\
\text { experience }\end{array}$ & $\begin{array}{l}\text { INTERNATIONAL JOURNAL OF } \\
\text { SUSTAINABLE } \\
\text { DEVELOPMENT AND WORLD } \\
\text { ECOLOGY }\end{array}$ & 12 & 1 & 21 & 33 \\
\hline Marschke, MJ; Berkes, F & 2006 & $\begin{array}{l}\text { Exploring strategies that build livelihood resilience: a case from } \\
\text { Cambodia }\end{array}$ & ECOLOGY AND SOCIETY & 11 & 1 & & \\
\hline Marshall, GR; Smith, DMS & 2010 & $\begin{array}{l}\text { Natural resources governance for the drylands of the Murray-Darling } \\
\text { Basin }\end{array}$ & RANGELAND JOURNAL & 32 & 3 & 267 & 282 \\
\hline Marshall, NA; Marshall, PA & 2007 & $\begin{array}{l}\text { Conceptualizing and operationalizing social resilience within commercial } \\
\text { fisheries in northern Australia }\end{array}$ & ECOLOGY AND SOCIETY & 12 & 1 & & \\
\hline Matthews, R; Selman, $\mathrm{P}$ & 2006 & $\begin{array}{l}\text { Landscape as a focus for integrating human and environmental } \\
\text { processes }\end{array}$ & $\begin{array}{l}\text { JOURNAL OF AGRICULTURAL } \\
\text { ECONOMICS }\end{array}$ & 57 & 2 & 199 & 212 \\
\hline $\begin{array}{l}\text { McAllister, RRJ; Abel, N; Stokes, CJ; Gordon, } \\
\text { IJ }\end{array}$ & 2006 & $\begin{array}{l}\text { Australian pastoralists in time and space: The evolution of a complex } \\
\text { adaptive system }\end{array}$ & ECOLOGY AND SOCIETY & 11 & 2 & & \\
\hline McFadden, L; Penning-Rowsell, E; Tapsell, S & 2009 & $\begin{array}{l}\text { Strategic coastal flood-risk management in practice: Actors' } \\
\text { perspectives on the integration of flood risk management in London and } \\
\text { the Thames Estuary }\end{array}$ & $\begin{array}{l}\text { OCEAN \& COASTAL } \\
\text { MANAGEMENT }\end{array}$ & 52 & 12 & 636 & 645 \\
\hline
\end{tabular}




\begin{tabular}{|c|c|c|c|c|c|c|c|}
\hline McIntyre, $\mathrm{N}$ & 2009 & $\begin{array}{l}\text { Rethinking Amenity Migration: Integrating Mobility, Lifestyle and Social- } \\
\text { Ecological Systems }\end{array}$ & ERDE & 140 & 3 & 229 & 250 \\
\hline Milestad, R; Darnhofer, I & 2003 & $\begin{array}{l}\text { Building farm resilience: The prospects and challenges of organic } \\
\text { farming }\end{array}$ & $\begin{array}{l}\text { JOURNAL OF SUSTAINABLE } \\
\text { AGRICULTURE }\end{array}$ & 22 & 3 & 81 & 97 \\
\hline $\begin{array}{l}\text { Milestad, R; Westberg, L; Geber, U; Bjorklund, } \\
\mathrm{J}\end{array}$ & 2010 & $\begin{array}{l}\text { Enhancing Adaptive Capacity in Food Systems: Learning at Farmers' } \\
\text { Markets in Sweden }\end{array}$ & ECOLOGY AND SOCIETY & 15 & 3 & & \\
\hline $\begin{array}{l}\text { Miller, F; Osbahr, H; Boyd, E; Thomalla, F; } \\
\text { Bharwani, S; Ziervogel, G; Walker, B; } \\
\text { Birkmann, J; van der Leeuw, S; Rockstrom, J; } \\
\text { Hinkel, J; Downing, T; Folke, C; Nelson, D }\end{array}$ & 2010 & Resilience and Vulnerability: Complementary or Conflicting Concepts? & ECOLOGY AND SOCIETY & 15 & 3 & & \\
\hline $\begin{array}{l}\text { Miller, TR; Baird, TD; Littlefield, CM; Kofinas, } \\
\text { G; Chapin, FS; Redman, CL }\end{array}$ & 2008 & Epistemological Pluralism: Reorganizing Interdisciplinary Research & ECOLOGY AND SOCIETY & 13 & 2 & & \\
\hline Milman, A; Short, A & 2008 & $\begin{array}{l}\text { Incorporating resilience into sustainability indicators: An example for the } \\
\text { urban water sector }\end{array}$ & $\begin{array}{l}\text { GLOBAL ENVIRONMENTAL } \\
\text { CHANGE-HUMAN AND POLICY } \\
\text { DIMENSIONS }\end{array}$ & 18 & 4 & 758 & 767 \\
\hline Moen, J; Keskitalo, ECH & 2010 & Interlocking panarchies in multi-use boreal forests in Sweden & ECOLOGY AND SOCIETY & 15 & 3 & & \\
\hline Moser, SC & 2010 & $\begin{array}{l}\text { Now more than ever: The need for more societally relevant research on } \\
\text { vulnerability and adaptation to climate change }\end{array}$ & APPLIED GEOGRAPHY & 30 & 4 & 464 & 474 \\
\hline $\begin{array}{l}\text { Munoz-Erickson, TA; Aguilar-Gonzalez, B; } \\
\text { Sisk, TD }\end{array}$ & 2007 & $\begin{array}{l}\text { Linking ecosystem health indicators and collaborative management: a } \\
\text { systematic framework to evaluate ecological and social outcomes }\end{array}$ & ECOLOGY AND SOCIETY & 12 & 2 & & \\
\hline Nelson, DR; Adger, WN; Brown, K & 2007 & $\begin{array}{l}\text { Adaptation to environmental change: Contributions of a resilience } \\
\text { framework }\end{array}$ & $\begin{array}{l}\text { ANNUAL REVIEW OF } \\
\text { ENVIRONMENT AND } \\
\text { RESOURCES }\end{array}$ & 32 & & 395 & 419 \\
\hline Nelson, DR; Finan, TJ & 2009 & $\begin{array}{l}\text { Praying for Drought: Persistent Vulnerability and the Politics of } \\
\text { Patronage in Ceara, Northeast Brazil }\end{array}$ & $\begin{array}{l}\text { AMERICAN } \\
\text { ANTHROPOLOGIST }\end{array}$ & 111 & 3 & 302 & 316 \\
\hline $\begin{array}{l}\text { Nelson, R; Kokic, P; Crimp, S; Meinke, H; } \\
\text { Howden, SM }\end{array}$ & 2010 & $\begin{array}{l}\text { The vulnerability of Australian rural communities to climate variability } \\
\text { and change: Part I-Conceptualising and measuring vulnerability }\end{array}$ & $\begin{array}{l}\text { ENVIRONMENTAL SCIENCE \& } \\
\text { POLICY }\end{array}$ & 13 & 1 & 8 & 17 \\
\hline Nkhata, BA; Breen, C & 2010 & $\begin{array}{l}\text { A Framework for Exploring Integrated Learning Systems for the } \\
\text { Governance and Management of Public Protected Areas }\end{array}$ & $\begin{array}{l}\text { ENVIRONMENTAL } \\
\text { MANAGEMENT }\end{array}$ & 45 & 2 & 403 & 413 \\
\hline Nkhata, BA; Breen, CM & 2010 & $\begin{array}{l}\text { Performance of community-based natural resource governance for the } \\
\text { Kafue Flats (Zambia) }\end{array}$ & $\begin{array}{l}\text { ENVIRONMENTAL } \\
\text { CONSERVATION }\end{array}$ & 37 & 3 & 296 & 302 \\
\hline O'Brien, K; Hayward, B; Berkes, F & 2009 & Rethinking Social Contracts: Building Resilience in a Changing Climate & ECOLOGY AND SOCIETY & 14 & 2 & & \\
\hline Olsson, $\mathrm{P} ;$ Folke, C & 2001 & $\begin{array}{l}\text { Local ecological knowledge and institutional dynamics for ecosystem } \\
\text { management: A study of Lake Racken Watershed, Sweden }\end{array}$ & ECOSYSTEMS & 4 & 2 & 85 & 104 \\
\hline Olsson, P; Folke, C; Berkes, F & $2004 a$ & $\begin{array}{l}\text { Adaptive comanagement for building resilience in social-ecological } \\
\text { systems }\end{array}$ & $\begin{array}{l}\text { ENVIRONMENTAL } \\
\text { MANAGEMENT }\end{array}$ & 34 & 1 & 75 & 90 \\
\hline $\begin{array}{l}\text { Olsson, P; Folke, C; Galaz, V; Hahn, T; } \\
\text { Schultz, L }\end{array}$ & 2007 & $\begin{array}{l}\text { Enhancing the fit through adaptive co-management: Creating and } \\
\text { maintaining bridging functions for matching scales in the Kristianstads } \\
\text { Vattenrike Biosphere Reserve, Sweden }\end{array}$ & ECOLOGY AND SOCIETY & 12 & 1 & & \\
\hline Olsson, P; Folke, C; Hahn, T & $2004 b$ & $\begin{array}{l}\text { Social-ecological transformation for ecosystem management: the } \\
\text { development of adaptive co-management of a wetland landscape in } \\
\text { southern Sweden }\end{array}$ & ECOLOGY AND SOCIETY & 9 & 4 & & \\
\hline
\end{tabular}


Olsson, P; Gunderson, LH; Carpenter, SR; Ryan, P; Lebel, L; Folke, C; Holling, CS

O'Rourke, E

Osbahr, H; Twyman, C; Adger, WN; Thomas

DSG

Osbahr, H; Twyman, C; Adger, WN; Thomas,

DSG

Peter, C; de Lange, W; Musango, JK; April, K; Potgieter, A

Plummer, $\mathrm{R}$

Plummer, $\mathrm{R}$

Plummer, R; Fennell, DA

Powell, RB; Cuschnir, A; Peiris, P

Rammel, C; Stagl, S; Wilfing, H

Renaud, FG; Birkmann, J; Damm, M; Gallopin, 2010 GC

Rescia, AJ; Pons, A; Lomba, I; Esteban, C;

Dover, JW

Rescia, AJ; Willaarts, BA; Schmitz, MF;

Aguilera, PA

Robards, M; Alessa, L

Robinson, LW

Romieu, E; Welle, T; Schneiderbauer, S

Pelling, M; Vinchon, $C$

Saavedra, C; Budd, WW

Sandstrom, A; Rova, C

Schianetz, K; Kavanagh, L

Schluter, M; Leslie, H; Levin, S

Schluter, M; Pahl-Wostl, C

2009
2006 Shooting the rapids: Navigating transitions to adaptive governance of social-ecological systems

2006 Biodiversity and land use change on the Causse Mejan, France

Effective livelihood adaptation to climate change disturbance: Scale dimensions of practice in Mozambique

2010

Sucrion Change in Southern Africa

Applying Bayesian modelling to assess climate change effects on biofuel production

2009 The Adaptive Co-Management Process: an Initial Synthesis of Representative Models and Influential Variables

2010 Social-ecological resilience and environmental education: synopsis, application, implications

2009 Managing protected areas for sustainable tourism: prospects for adaptive co-management

2009 Overcoming Governance and Institutional Barriers to Integrated Coasta Zone, Marine Protected Area, and Tourism Management in Sri Lanka

Managing complex adaptive systems - A co-evolutionary perspective on natural resource management

Understanding multiple thresholds of coupled social-ecological systems exposed to natural hazards as external shocks

2008 Reformulating the social-ecological system in a cultural rural mountain

2010 Changes in land uses and management in two Nature Reserves in Spain: Evaluating the social-ecological resilience of cultural landscapes

2004 Timescapes of community resilience and vulnerability in the circumpolar north

Vulnerability assessment within climate change and natural hazard contexts: revealing gaps and synergies through coastal applications

2009 Climate change and environmental planning: Working to build community resilience and adaptive capacity in Washington State, USA

2010 Adaptive Co-management Networks: a Comparative Analysis of Two Fishery Conservation Areas in Sweden

2008 Sustainability Indicators for Tourism Destinations: A Complex Adaptive Systems Approach Using Systemic Indicator Systems

2009 Managing water-use trade-offs in a semi-arid river delta to sustain multiple ecosystem services: a modeling approach

2007 Mechanisms of resilience in common-pool resource management systems: an agent-based model of water use in a river basin

\begin{tabular}{|c|c|c|c|c|}
\hline ECOLOGY AND SOCIETY & 11 & 1 & & \\
\hline $\begin{array}{l}\text { BIODIVERSITY AND } \\
\text { CONSERVATION }\end{array}$ & 15 & 8 & 2611 & 2626 \\
\hline GEOFORUM & 39 & 6 & 1951 & 1964 \\
\hline ECOLOGY AND SOCIETY & 15 & 2 & & \\
\hline CLIMATE RESEARCH & 40 & 40577 & 249 & 260 \\
\hline ECOLOGY AND SOCIETY & 14 & 2 & & \\
\hline $\begin{array}{l}\text { ENVIRONMENTAL } \\
\text { EDUCATION RESEARCH }\end{array}$ & 16 & 40669 & 493 & 509 \\
\hline $\begin{array}{l}\text { JOURNAL OF SUSTAINABLE } \\
\text { TOURISM }\end{array}$ & 17 & 2 & 149 & 168 \\
\hline COASTAL MANAGEMENT & 37 & 6 & 633 & 655 \\
\hline ECOLOGICAL ECONOMICS & 63 & 1 & 9 & 21 \\
\hline NATURAL HAZARDS & 55 & 3 & 749 & 763 \\
\hline $\begin{array}{l}\text { LANDSCAPE AND URBAN } \\
\text { PLANNING }\end{array}$ & 88 & 1 & 23 & 33 \\
\hline $\begin{array}{l}\text { LANDSCAPE AND URBAN } \\
\text { PLANNING }\end{array}$ & 98 & 1 & 26 & 35 \\
\hline ARCTIC & 57 & 4 & 415 & 427 \\
\hline HUMAN ECOLOGY & 37 & 4 & 441 & 451 \\
\hline SUSTAINABILITY SCIENCE & 5 & 2 & 159 & 170 \\
\hline HABITAT INTERNATIONAL & 33 & 3 & 246 & 252 \\
\hline ECOLOGY AND SOCIETY & 15 & 3 & & \\
\hline $\begin{array}{l}\text { JOURNAL OF SUSTAINABLE } \\
\text { TOURISM }\end{array}$ & 16 & 6 & 601 & 628 \\
\hline ECOLOGICAL RESEARCH & 24 & 3 & 491 & 503 \\
\hline ECOLOGY AND SOCIETY & 12 & 2 & & \\
\hline
\end{tabular}




\begin{tabular}{|c|c|c|c|c|c|c|c|}
\hline Schultz, L; Lundholm, C & 2010 & $\begin{array}{l}\text { Learning for resilience? Exploring learning opportunities in biosphere } \\
\text { reserves }\end{array}$ & $\begin{array}{l}\text { ENVIRONMENTAL } \\
\text { EDUCATION RESEARCH }\end{array}$ & 16 & 40669 & 645 & 663 \\
\hline $\begin{array}{l}\text { Sendzimir, J; Magnuszewski, P; Flachner, Z; } \\
\text { Balogh, P; Molnar, G; Sarvari, A; Nagy, Z }\end{array}$ & 2008 & $\begin{array}{l}\text { Assessing the Resilience of a River Management Regime: Informal } \\
\text { Learning in a Shadow Network in the Tisza River Basin }\end{array}$ & ECOLOGY AND SOCIETY & 13 & 1 & & \\
\hline $\begin{array}{l}\text { Serrat-Capdevila, A; Browning-Aiken, A; } \\
\text { Lansey, K; Finan, T; Valdes, JB }\end{array}$ & 2009 & $\begin{array}{l}\text { Increasing Social-Ecological Resilience by Placing Science at the } \\
\text { Decision Table: the Role of the San Pedro Basin (Arizona) Decision- } \\
\text { Support System Model }\end{array}$ & ECOLOGY AND SOCIETY & 14 & 1 & & \\
\hline Smith, A; Stirling, A & 2010 & $\begin{array}{l}\text { The Politics of Social-ecological Resilience and Sustainable Socio- } \\
\text { technical Transitions }\end{array}$ & ECOLOGY AND SOCIETY & 15 & 1 & & \\
\hline $\begin{array}{l}\text { Spies, TA; Giesen, TW; Swanson, FJ; Franklin, } \\
\text { JF; Lach, D; Johnson, KN }\end{array}$ & 2010 & $\begin{array}{l}\text { Climate change adaptation strategies for federal forests of the Pacific } \\
\text { Northwest, USA: ecological, policy, and socio-economic perspectives }\end{array}$ & LANDSCAPE ECOLOGY & 25 & 8 & 1185 & 1199 \\
\hline Steinberg, PF & 2009 & $\begin{array}{l}\text { Institutional Resilience Amid Political Change: The Case of Biodiversity } \\
\text { Conservation }\end{array}$ & $\begin{array}{l}\text { GLOBAL ENVIRONMENTAL } \\
\text { POLITICS }\end{array}$ & 9 & 3 & 61 & + \\
\hline Strickland-Munro, JK; Allison, HE; Moore, SA & 2010 & $\begin{array}{l}\text { USING RESILIENCE CONCEPTS TO INVESTIGATE THE IMPACTS } \\
\text { OF PROTECTED AREA TOURISM ON COMMUNITIES }\end{array}$ & $\begin{array}{l}\text { ANNALS OF TOURISM } \\
\text { RESEARCH }\end{array}$ & 37 & 2 & 499 & 519 \\
\hline $\begin{array}{l}\text { Tidball, KG; Krasny, ME; Svendsen, E; } \\
\text { Campbell, L; Helphand, K }\end{array}$ & 2010 & Stewardship, learning, and memory in disaster resilience & \begin{tabular}{|l} 
ENVIRONMENTAL \\
EDUCATION RESEARCH
\end{tabular} & 16 & 40669 & 591 & 609 \\
\hline $\begin{array}{l}\text { Trainor, SF; Calef, M; Natcher, D; Chapin, FS; } \\
\text { McGuire, AD; Huntington, O; Duffy, P; Rupp, } \\
\text { TS; DeWilde, L; Kwart, M; Fresco, N; Lovecraft, } \\
\text { AL }\end{array}$ & 2009 & $\begin{array}{l}\text { Vulnerability and adaptation to climate-related fire impacts in rural and } \\
\text { urban interior Alaska }\end{array}$ & POLAR RESEARCH & 28 & 1 & 100 & 118 \\
\hline $\begin{array}{l}\text { Tschakert, P; Huber-Sannwald, E; Ojima, DS; } \\
\text { Raupach, MR; Schienke, E }\end{array}$ & 2008 & $\begin{array}{l}\text { Holistic, adaptive management of the terrestrial carbon cycle at local } \\
\text { and regional scales }\end{array}$ & $\begin{array}{l}\text { GLOBAL ENVIRONMENTAL } \\
\text { CHANGE-HUMAN AND POLICY } \\
\text { DIMENSIONS }\end{array}$ & 18 & 1 & 128 & 141 \\
\hline Turner, BL & 2010 & $\begin{array}{l}\text { Vulnerability and resilience: Coalescing or paralleling approaches for } \\
\text { sustainability science? }\end{array}$ & $\begin{array}{l}\text { GLOBAL ENVIRONMENTAL } \\
\text { CHANGE-HUMAN AND POLICY } \\
\text { DIMENSIONS }\end{array}$ & 20 & 4 & 570 & 576 \\
\hline $\begin{array}{l}\text { Turner, RA; Cakacaka, A; Graham, NAJ; } \\
\text { Polunin, NVC; Pratchett, MS; Stead, SM; } \\
\text { Wilson, SK }\end{array}$ & 2007 & $\begin{array}{l}\text { Declining reliance on marine resources in remote South Pacific } \\
\text { societies: ecological versus socio-economic drivers }\end{array}$ & CORAL REEFS & 26 & 4 & 997 & 1008 \\
\hline $\begin{array}{l}\text { Tyler, NJC; Turi, JM; Sundset, MA; Bull, KS; } \\
\text { Sara, MN; Reinert, E; Oskal, N; Nellemann, C; } \\
\text { McCarthy, JJ; Mathiesen, SD; Martello, ML; } \\
\text { Magga, OH; Hovelsrud, GK; Hanssen-Bauer, I; } \\
\text { Eira, NI; Eira, IMG; Corell, RW } \\
\end{array}$ & 2007 & $\begin{array}{l}\text { Saami reindeer pastoralism under climate change: Applying a } \\
\text { generalized framework for vulnerability studies to a sub-arctic social- } \\
\text { ecological system }\end{array}$ & $\begin{array}{l}\text { GLOBAL ENVIRONMENTAL } \\
\text { CHANGE-HUMAN AND POLICY } \\
\text { DIMENSIONS }\end{array}$ & 17 & 2 & 191 & 206 \\
\hline $\begin{array}{l}\text { Walker, B; Carpenter, S; Anderies, J; Abel, N; } \\
\text { Cumming, G; Janssen, M; Lebel, L; Norberg, J; } \\
\text { Peterson, GD; Pritchard, R }\end{array}$ & 2002 & $\begin{array}{l}\text { Resilience management in social-ecological systems: a working } \\
\text { hypothesis for a participatory approach }\end{array}$ & CONSERVATION ECOLOGY & 6 & 1 & & \\
\hline $\begin{array}{l}\text { Walker, B; Gunderson, L; Kinzig, A; Folke, C; } \\
\text { Carpenter, S; Schultz, L }\end{array}$ & 2006 & $\begin{array}{l}\text { A handful of heuristics and some propositions for understanding } \\
\text { resilience in social-ecological systems }\end{array}$ & ECOLOGY AND SOCIETY & 11 & 1 & & \\
\hline Walker, B; Hollin, CS; Carpenter, SR; Kinzig, A & 2004 & Resilience, adaptability and transformability in social-ecological systems & ECOLOGY AND SOCIETY & 9 & 2 & & \\
\hline Walker, BH; Abel, N; Anderies, JM; Ryan, P & 2009 & $\begin{array}{l}\text { Resilience, Adaptability, and Transformability in the Goulburn-Broken } \\
\text { Catchment, Australia }\end{array}$ & ECOLOGY AND SOCIETY & 14 & 1 & & \\
\hline
\end{tabular}




\begin{tabular}{|c|c|c|c|c|c|c|c|}
\hline van der Brugge, R; van Raak, $\mathrm{R}$ & 2007 & $\begin{array}{l}\text { Facing the adaptive management challenge: Insights from transition } \\
\text { management }\end{array}$ & ECOLOGY AND SOCIETY & 12 & 2 & & \\
\hline Wang, $\mathrm{CH}$; Blackmore, JM & 2009 & Resilience Concepts for Water Resource Systems & \begin{tabular}{|l|} 
JOURNAL OF WATER \\
RESOURCES PLANNING AND \\
MANAGEMENT-ASCE
\end{tabular} & 135 & 6 & 528 & 536 \\
\hline $\begin{array}{l}\text { Wardekker, JA; de Jong, A; Knoop, JM; van } \\
\text { der Sluijs, JP }\end{array}$ & 2010 & $\begin{array}{l}\text { Operationalising a resilience approach to adapting an urban delta to } \\
\text { uncertain climate changes }\end{array}$ & $\begin{array}{l}\text { TECHNOLOGICAL } \\
\text { FORECASTING AND SOCIAL } \\
\text { CHANGE }\end{array}$ & 77 & 6 & 987 & 998 \\
\hline Warner, K & 2010 & Global environmental change and migration: Governance challenges & $\begin{array}{l}\text { GLOBAL ENVIRONMENTAL } \\
\text { CHANGE-HUMAN AND POLICY } \\
\text { DIMENSIONS }\end{array}$ & 20 & 3 & 402 & 413 \\
\hline Vetter, S & 2009 & $\begin{array}{l}\text { Drought, change and resilience in South Africa's arid and semi-arid } \\
\text { rangelands }\end{array}$ & $\begin{array}{l}\text { SOUTH AFRICAN JOURNAL } \\
\text { OF SCIENCE }\end{array}$ & 105 & 40545 & 29 & 33 \\
\hline Yang, LH; Wu, JG & 2009 & $\begin{array}{l}\text { Scholar-participated governance as an alternative solution to the } \\
\text { problem of collective action in social-ecological systems }\end{array}$ & ECOLOGICAL ECONOMICS & 68 & 40764 & 2412 & 2425 \\
\hline Young, OR & 2010 & $\begin{array}{l}\text { Institutional dynamics: Resilience, vulnerability and adaptation in } \\
\text { environmental and resource regimes }\end{array}$ & $\begin{array}{l}\text { GLOBAL ENVIRONMENTAL } \\
\text { CHANGE-HUMAN AND POLICY } \\
\text { DIMENSIONS }\end{array}$ & 20 & 3 & 378 & 385 \\
\hline $\begin{array}{l}\text { Young, OR; Berkhout, F; Gallopin, GC; } \\
\text { Janssen, MA; Ostrom, E; Leeuw, SVD }\end{array}$ & 2006 & $\begin{array}{l}\text { The globalization of socio-ecological systems: An agenda for scientific } \\
\text { research }\end{array}$ & $\begin{array}{l}\text { GLOBAL ENVIRONMENTAL } \\
\text { CHANGE-HUMAN AND POLICY } \\
\text { DIMENSIONS } \\
\end{array}$ & 16 & 3 & 304 & 316 \\
\hline Zhou, HJ; Wang, JA; Wan, JH; Jia, HC & 2010 & Resilience to natural hazards: a geographic perspective & NATURAL HAZARDS & 53 & 1 & 21 & 41 \\
\hline
\end{tabular}

